\title{
مذهب السماع بين ابن عصفور وابن هشام' من خلال شرحيهما لجمل الزجاجي
}

د. حسن منصور أحمد سوركتي." لرجمي.

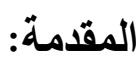

الحمدُ لله ربِّ العالمين، والصلاة والسلام على أشنرف خلق الله أجمعين، سيدنا وحبيينا محمد بن عبد الله الصادق الأمين، وعلى آله وصحبه الطاهرين، وبعد فإنَّ لكل نحوي منهجًا خاصنًا به يميزه عن غيره، وتأني أهمية تحديد ملامح المنهج في إطار الخلافات الكثيرة المبثوثة في الكتب بين أبناء المذهب الواحد، فالمبرد مثلاً يتعقب سيبويه وينتقده وهما بصريان، والفراء يخالف الكسائي ويعارضه وهما كوفيان والأمنتلة على ذلك كثيرة.

إذن فلا يرتبط النحوي بهذه الصفة حتى تكون له آراؤه الخاصة ومواققه التي يتمبز بها ويرى الباحث من الجدير أنْ يفرق في دراسة النحو بين منهج يقوم على التقليد المطلق ونقل آراء الآخرين دون أبي تغيير، وآخر يقوم على الابتكار والتجديد، والحاجة هنا ليست ملحة إلى التقصيل عن أصحاب هذين الاتجاهين فذلك كله من مستلزمات هذه الدراسة.

يتتاول هذا البحث السماع عند ابن عصفور وابن هشام من خلال شرحيهما لجمل الزجاجي، وقد جاء اختصاص الباحث لهذين العالمين؛ لأنَّ كليهما يمثل مدرسة نحوية قائمة بذاتها لها خصائصها وإرثها النحوي واللغوي الممتد، فابن عصفور يمثل المدرسة الأندلسية بينما يمنل ابن هشام المدرسة المصرية، والله

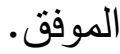

\footnotetext{
أستاذ مشارك- - جامعة السودان للعلوم والتكنولوجيا- كلية اللغات - قسم اللغة العربية $r \leqslant 0$
} 
تعريف السماع في اللغة والاصطلاح:

أ.تعريف السماع في اللغة:

لكلمة سماع في اللغة معان متعددة من ناحية المدلول،يقولون: "سمع سماعاً إذا

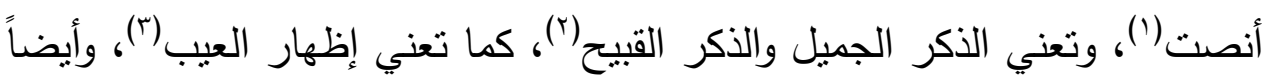
جاء المعنى لاسم بطنٍ من بطون العرب(؛)، كما جاءت بمعني الغناء(0).

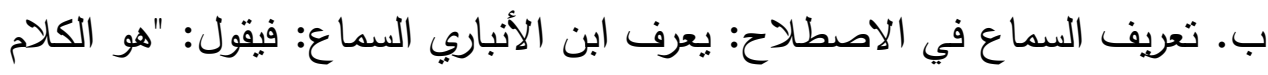
العربي المنقول النقل الصحيح الخارج عن حدّ القلة إلي حدّ الكثرة"(آن.

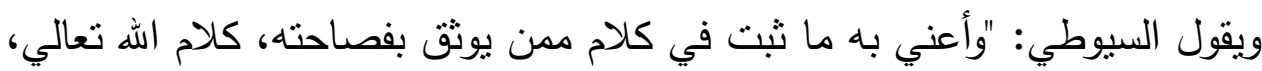

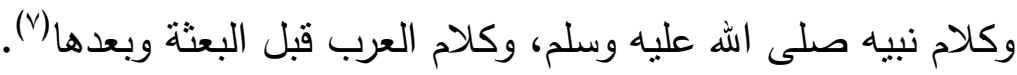

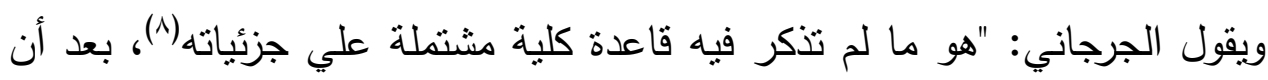

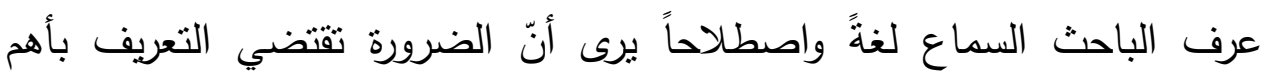

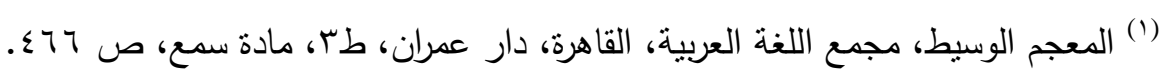
(Y) المحكم والمحيط الأعظم في اللغة، ابن سيده، مكتبة ومطبعة، مصطفى البابي الحلبي

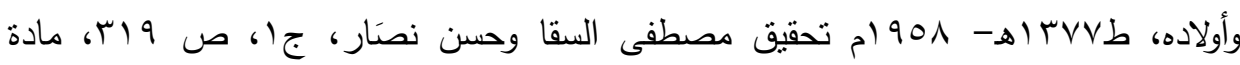

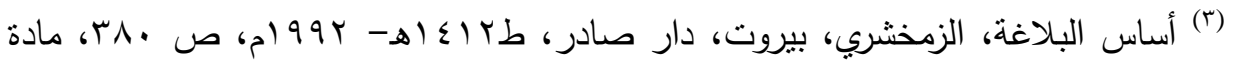

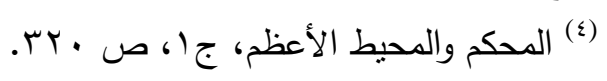

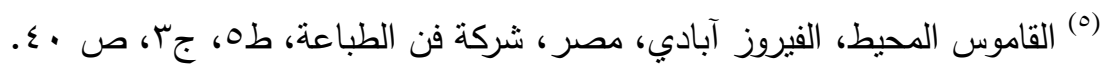

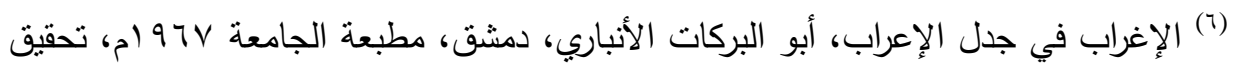

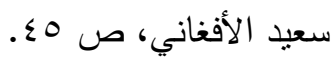

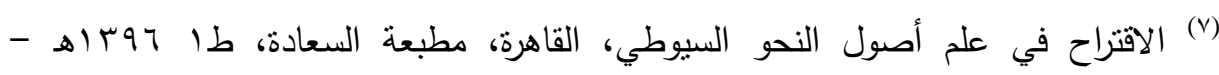

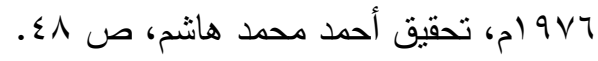


المصادر التي يعتمد عليها السماع، ولعل المقصود بالمصادر هنا ما سُمع منواتراً

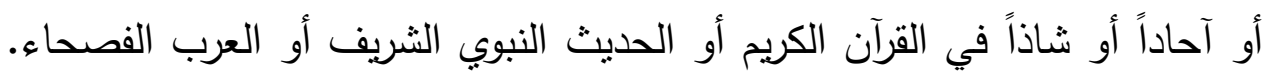

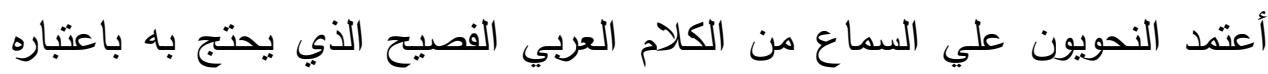

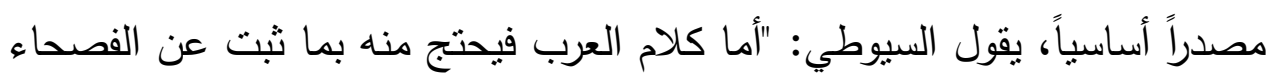
الموثوق بعربيتهم"(') ـ ويفصل السيوطي: "كانت قريش أجود العرب انتقاءً للأفصح

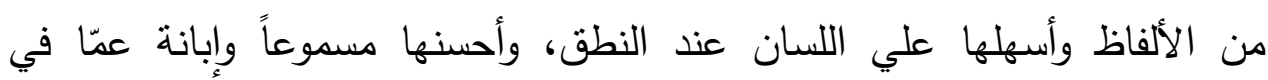
النفس، وأن الذين نقلوا اللغة واللسان العربي الفصيح بعد فساد الألسن وأثنتوها في واني

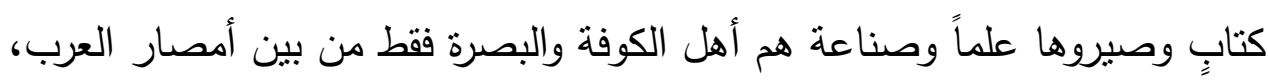

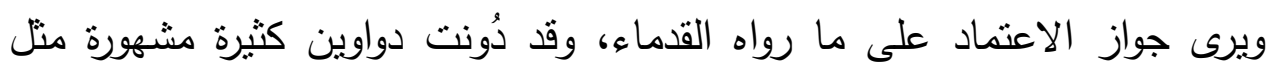

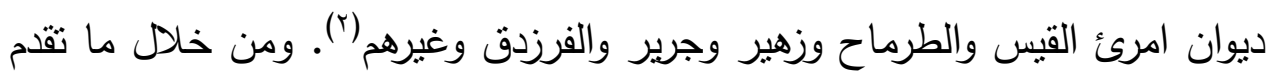
يتضح أن السماع يرتكز علي الأصول اللغوية ولا يخرج عليها وإن كان فصيحاً.

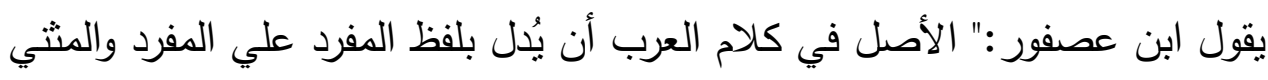

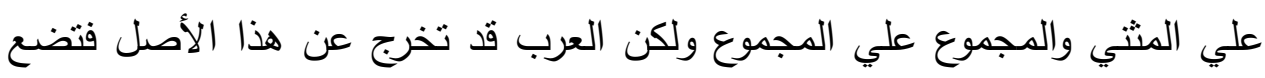
المفرد موضع المثني وموضع الجمع وتضع المثتي موضع الجمع وموضع المفرد

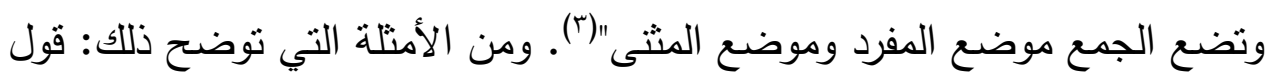
الثاعر:

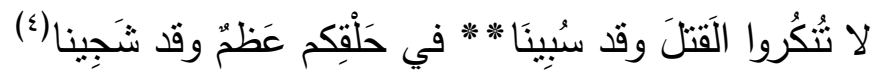

(A) كتاب التعريفات، الجرجاني، بيروت، دار الكتب العلمية، وضع فرعية، محمد بابل، ص ص

$$
\text { ؛ ا ـ فهارسه عيون السود، مادة "سمع". }
$$

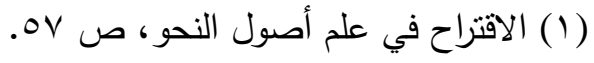

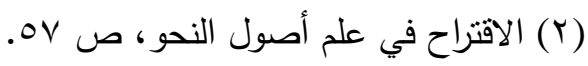

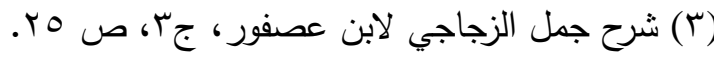

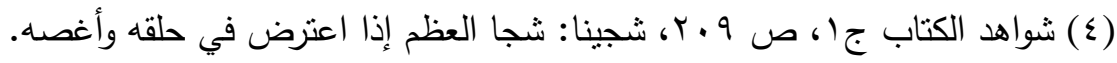


يريد في حلوقكم فوضع المفرد موضع الجمع وأجراه علي السماع(ه) ومنه قول الثاعر:

كأنّهَه وَجهُ تُركيين قد غَضِباِ(ا)

أراد "وجهًا ثُركيين "فوضع المفرد موضع الاثثين للضرورة('). ومن الأمثله قولهم:

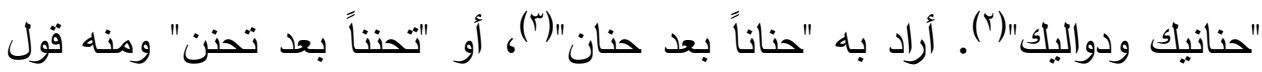
الثاعر:

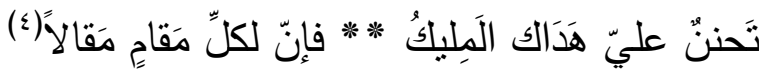

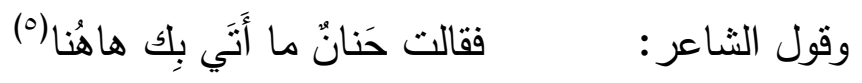

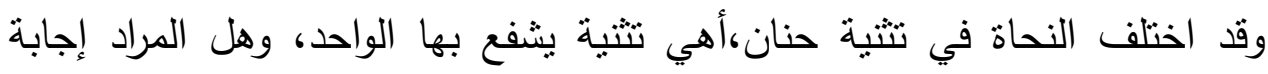

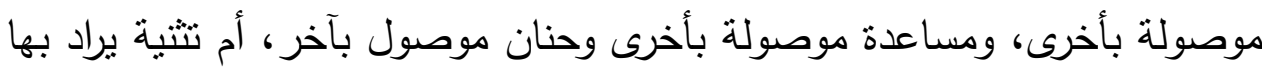

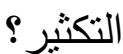

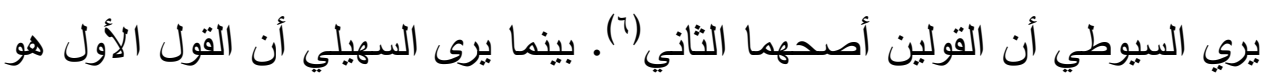

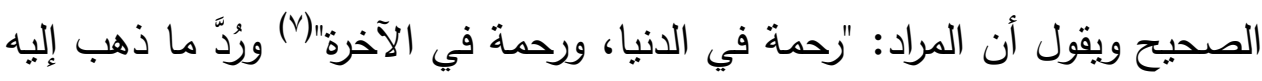

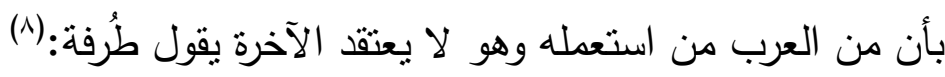

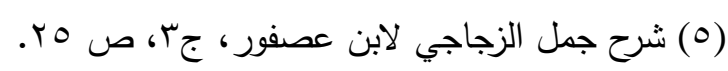

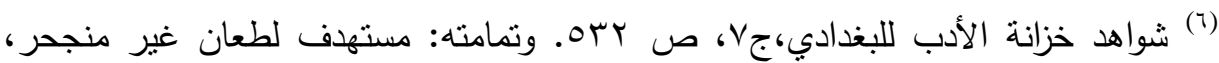

غير منجحر : لا ندخل الطعنات فيه.

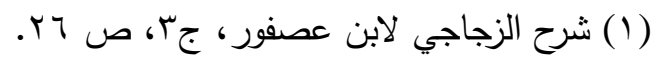

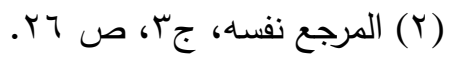

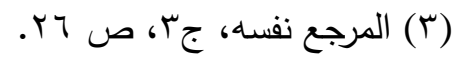

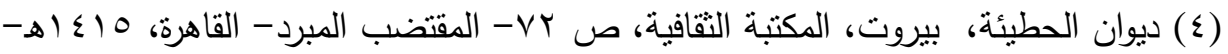

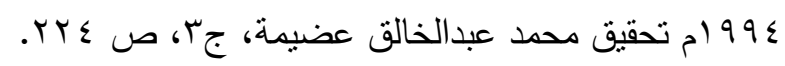

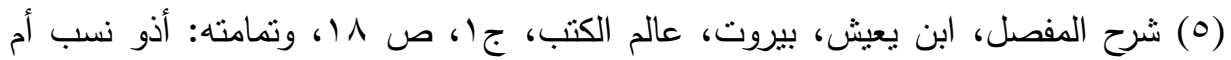


حنَانيكَ بعضُ الثرِّ أَهْونُ من بعَض

كما يذهب يونس إلى أنَّ "لبيك" اسم مفرد وأصله قبل الإضـافة "لبّا" مقصورة

قلبت ألفه ياءً لإضافته إلي الضمير كما قلبوا في لديك وعليك(9)، ويقول المبرد: "واعلم من المصادر التي لا أفعال لها تجري عليها وإنما يوضح موضع المصادر ما لإيا يكون مثني للمبالغة وذلك قولك "لبيك وسعديك وحنانيك"، إنما أراد "حنان بعد حنان"، أي كلما كنت في رحمة منك فلتكن موصولة بأخرى، ونأويل حنانيك إنما هو رحمة بعد رحمة يقال: تحنن فلان علي فلان إذا رحمه.والثاهد "تحنن عليّ هداك

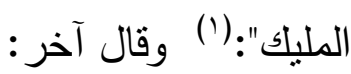

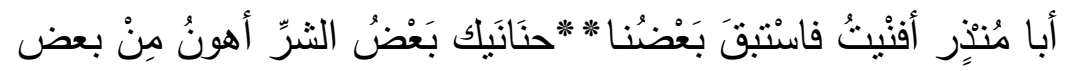

يقول المبرد: "فهذا مّما يجوز إفراده، فإن أفردت فأنت مخير وإن شئت نصبت بالفعل، وإن شئت ابتدأت، فإن ثثيت لم يكن إلاّ منصوباً لأنه وضع موضع مالا

$$
\text { يتمكن نحو : "لبيك وسعديك". }
$$

وأمّا تأويل قولهم "لبيك"، فإنّما يقال: "ألبّ فلان على الأمر إذا لزمه ودام عليه فمعناه: مداومة على إجابتك ومحافظة على حقلك (r) . يفصّل ابن يعيش: "إن حنانيك ودواليك الغرض من التثبية فيها التكثير، وأنه شيء يعود مرة بعد مرة وليس المراد منها الأثنين فقط كما تقول: "أدخلوا الأول فالأول"

$$
\begin{aligned}
& \text { (T) همع الهوامع، جr، ص r ז } \\
& \text { (V) المرجع نفسه، جr (V) }
\end{aligned}
$$

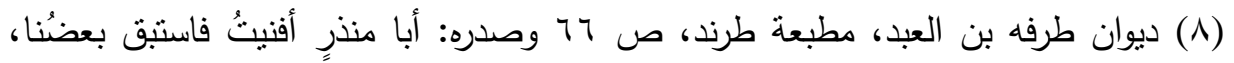

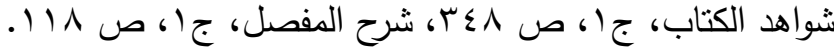

$$
\begin{aligned}
& \text { (9) همع الهوامع، جr، ص سمر. }
\end{aligned}
$$

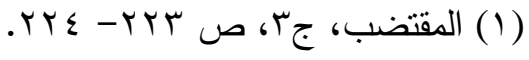

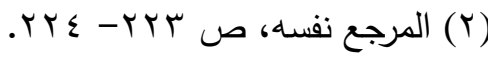


والغرض أن يدخل الجميع، وانتصابه على المصدر الموضوع موضع الفعل والتقدير : تحنن علينا تحنناً وثثي مبالغة وتكثيراً أي: "تحنن بعد تحنن ولم بقصد التهد بهابه

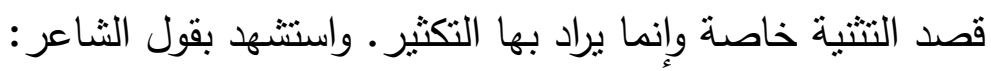

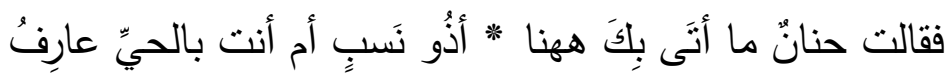

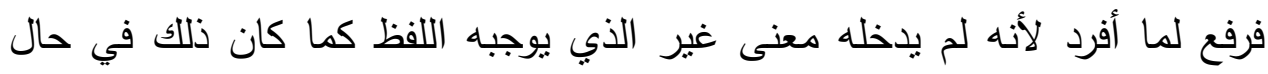

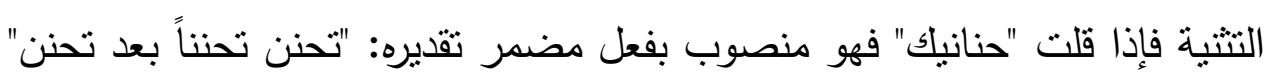
لكنهم حذفوا الفعل لأن المصدر صار بدلاً منه كما كان ذلك في "سقياً للك ورعياً"

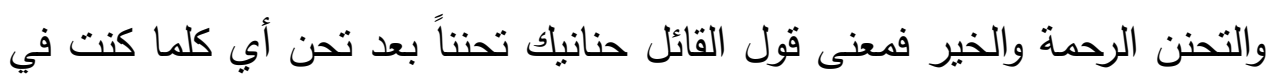
رحمة وخير فلا تقطعن ذلك وليكن موصولاً بآخر من رحمناك (r).

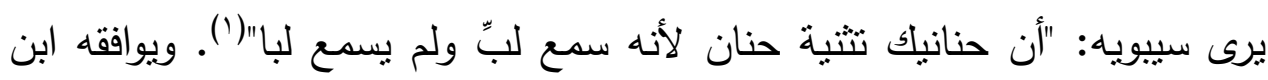
يعيش في تثية دواليك: يقول: "كأنه مأخوذ من المداولة وهي المناوبة فدواليك تثنية لتئية

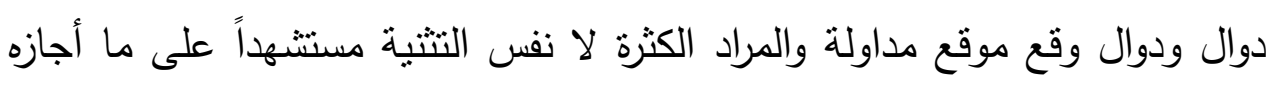
بقول الثاعر:

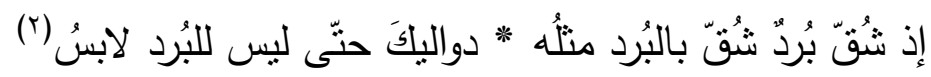

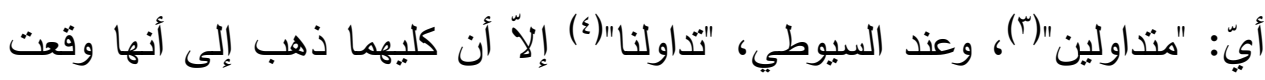
موقع الكثرة.

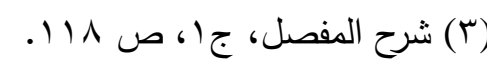

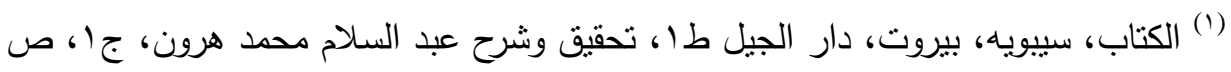


يقول ابن عصفور : "والمسموع الذي يحفظ ولا يقاس عليه كل شيء من شيء واحد أو مستقلين بأنفسهما منل قولهم: "رجل عظيم المناكب وليس له إلاًّ منكبان"(ه). يرى ابن هشام أن كل شيئين من شيئين فتثتيتهما جمع ويجوز ذلك سماعاً مستشهداً

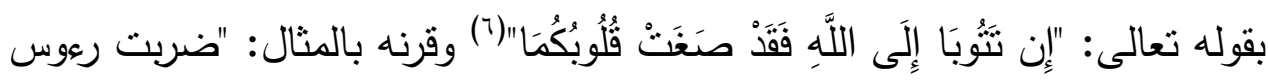
الزيدين". ويقول ابن هشام: ويجوز أن تقول "ضربت رأسيهما"، والأول أكثر في كلام العرب، أي: "قطعت رعوس الزيدين" - فكرهوا أن يجمعوا بين تثيتين في كلمة واحدة فصرفوا الأول إلى لفظ الجمع لأن التثنية جمع في المعنى ولأن معنى الجمع ضم شيء إلى شيء. وقد تقع على القليل والكثير (') وقد دعم موقفه بقول الراجز :

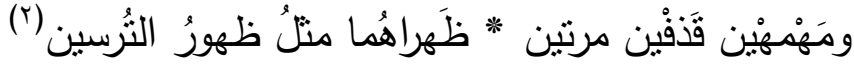

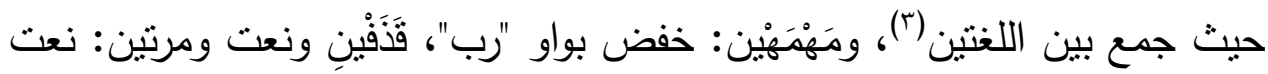
ظهراهما: ابتداء، مثل، خبره، الترسين: إضافة.

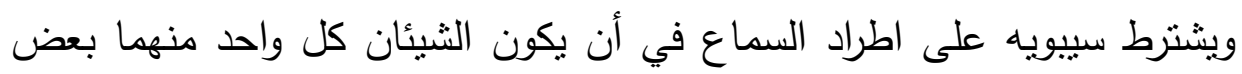
شيء مفرد من صاحبه وذلك قوللك: "ما أحسنَ رعوسهما وأحسن عواليهما"(ه)،

$$
\begin{aligned}
& \text { (0) شرح جمل الزجاجي، لابن عصفور، جr، ص VV. }
\end{aligned}
$$

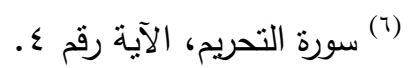

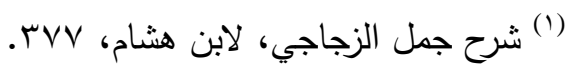

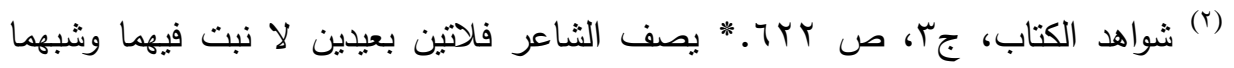

بالترسين في الاستواء: المهمة: الفلاة، القذف: بعيدة تثقاذف، المرة: المفازة التي لا نتبت فيها،

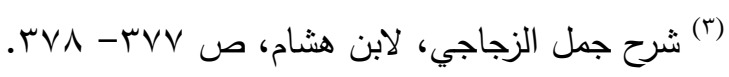

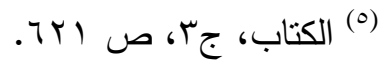




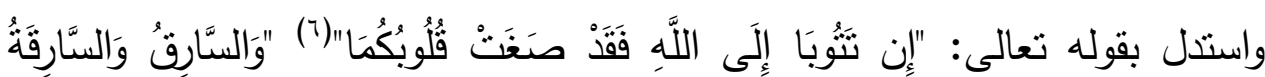

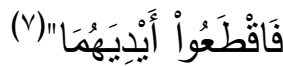

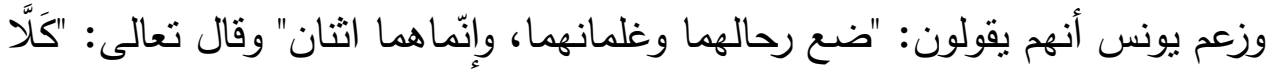

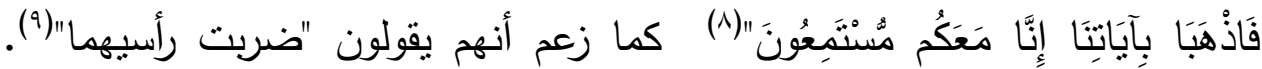

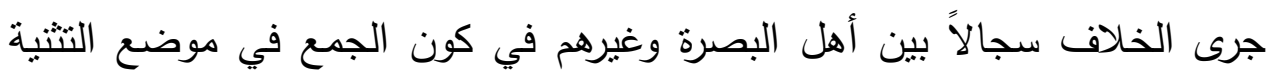

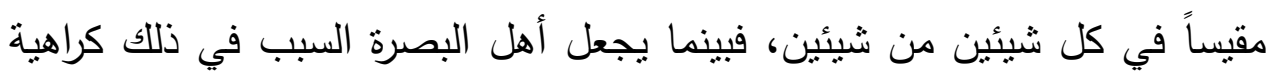

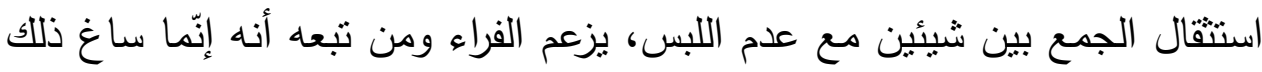

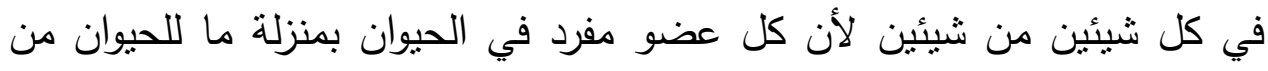

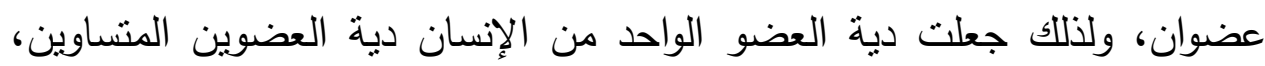

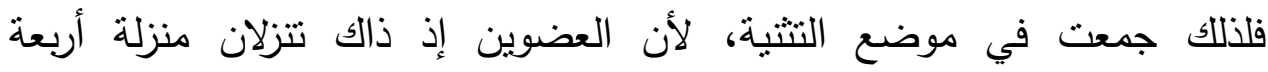

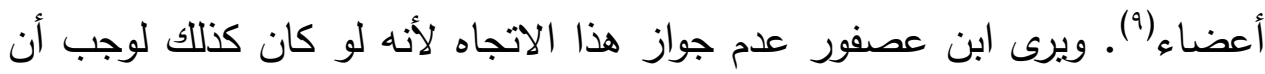

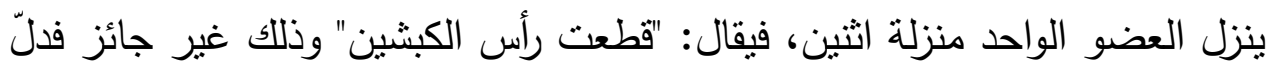

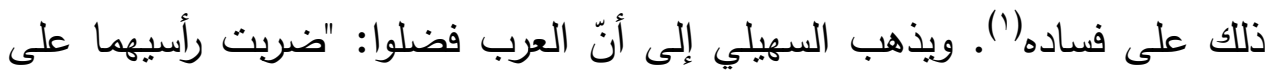

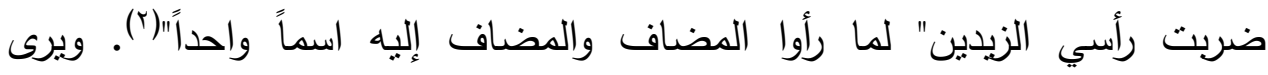

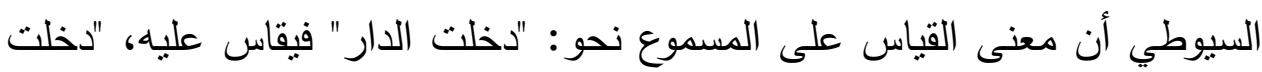

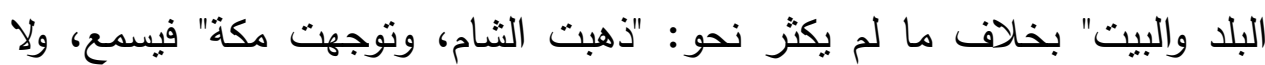

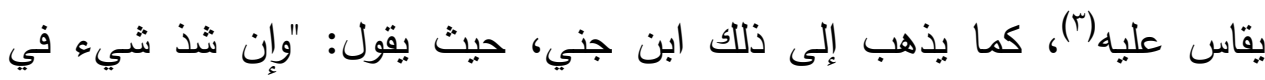

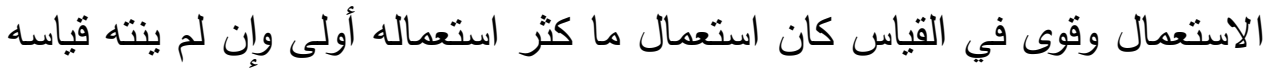

$$
\begin{aligned}
& \text { (T) سورة التحريم، الآية رقم ع. }
\end{aligned}
$$

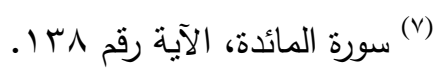

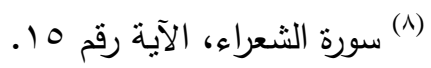

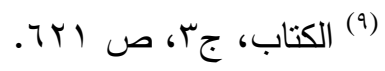

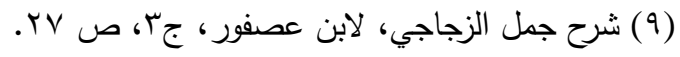

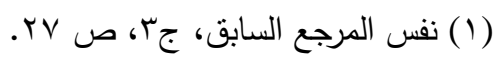

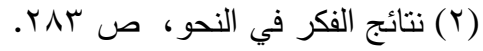

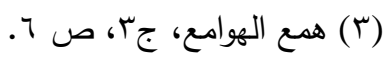




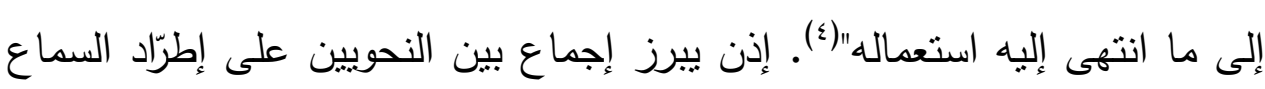

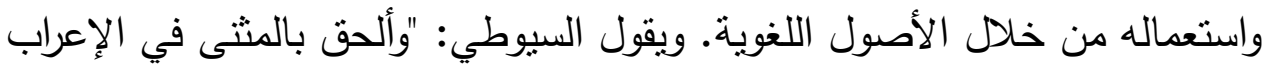

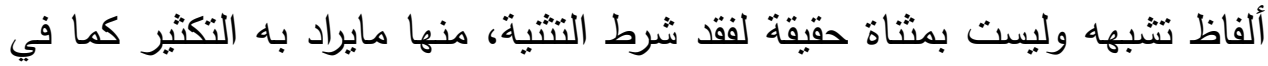

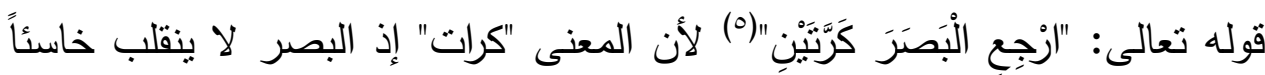

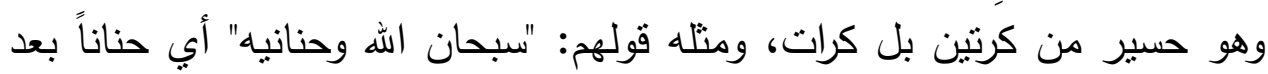

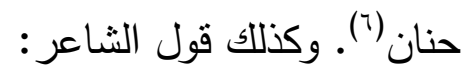
ومهَهُين قذفين مرتين.

أي مهمة بعد مهمة، وهذا النوع يجوز فيه التجريد من الزيادة والعطف. كما

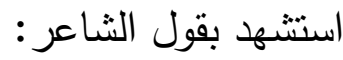

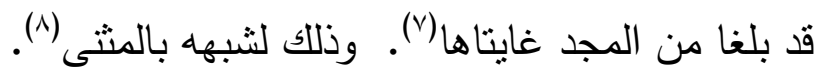

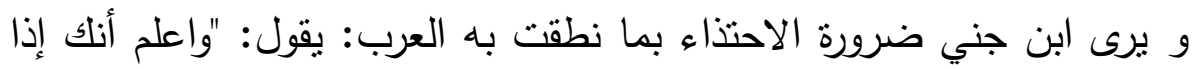

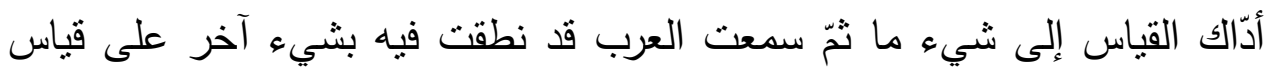

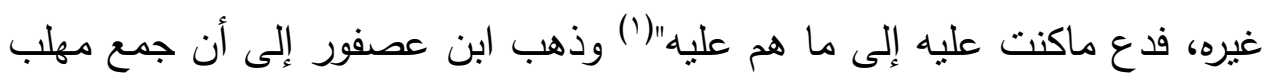

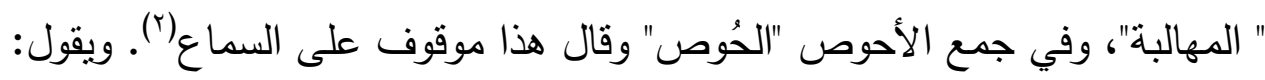

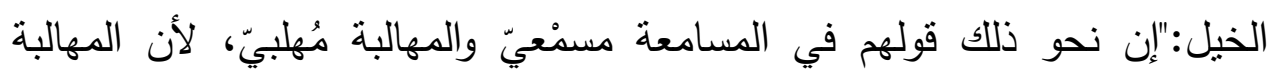

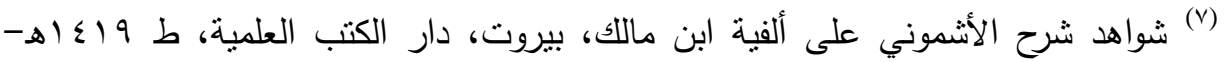

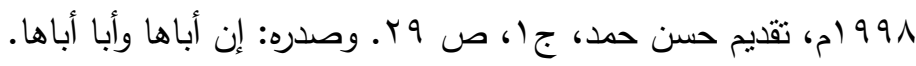

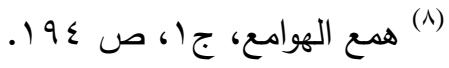

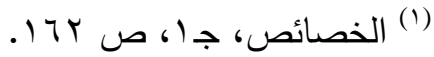

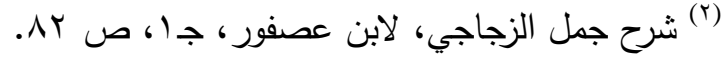


والمسامعة ليس منها واحد اسماً لواحد" (r) لقد كانت لابن عصفور آراء جريئة خالف فيها النحاة منها: يرى أن كل صفة للمذكر أو المؤنث لا يجوز جمعها بالواو والنون كما لا يجوز جمع المؤنث بالألف والتاء وإن جاء فهو موقوف على السماع، ويجوز في كل مصغر لما لا يعقل منل: "دُربهمات" "ودنُنينيرات" وماعدا ذلك لا يجوز جمعه بالألف والتاء إلاّ حيث سمع نحو : "حمامات وسرادقات"(؛). ويرى السيوطي أن ذلك شاذ (0).

ونقل ابن منظور أن "سرادقات" جمعوه بالتاء وإن كان مذكراً حين لم يكسر (؟). يقول ابن عصفور : "والذي لا يستعمل إلاّ في النداء خاصة ينقسم قسمين: مقيس ومسموع واءو فالمسموع: " باهناهُ وبافلُ واللهم " فأمّا "با هناه" فكناية عن النكرات" وأمّا "فُل" فكناية عن علم ولا يستعمل أبداً إلاّ في النداء وفي ضرورة الثعر (V). يوافق ابن هشام ابن عصفور في رأيه فيما بتعلق باستعمال "فَلُ" في ضرورة الثعر ولكن بخالفه في كونها كناية عن علم، حيث يرى أنها كناية عن الغائب وأنه ليس بترخيم ولو كان

$$
\text { ترخيما لقيل "يا فلا" (1) }
$$

ويرى ابن هثام أن " هناه" نداء مفرد ولا يقال: "رأيت هناه" لأنه اسم اثتمل على

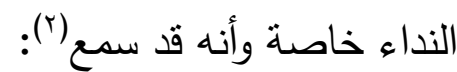

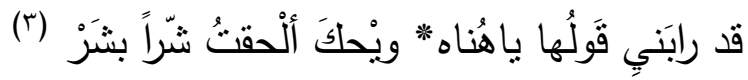

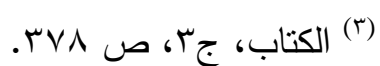

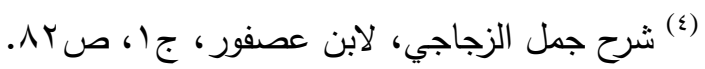

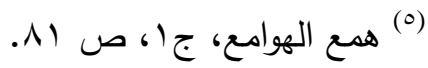

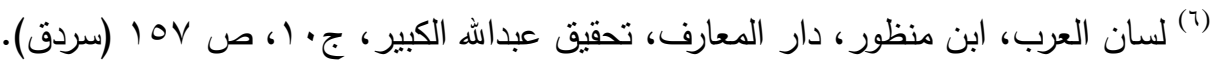

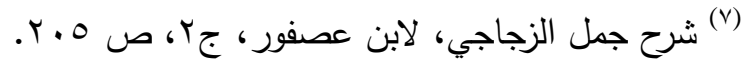

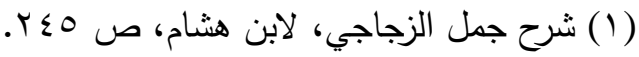

$$
\begin{aligned}
& \text { ros }
\end{aligned}
$$

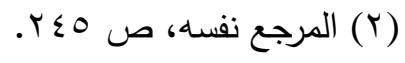


ويتفق معه ابن يعيش بقوله: فمعنى "يا هناه" "يارجل"، " وهناه" لا يستعمل إلاّ في

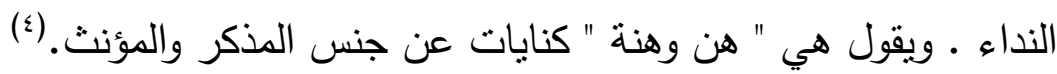

وقد ذكر الهرمي: من ذلك قولهم: "ياهناه أقبل" معناه " يارجل أقبل" وقد استشهد بقول أمرئ القيس السابق:

قد رابَني قَوَلُها ياهُناهُ * ويْحكَ ألْحقِتُ شُراً بشَرْ

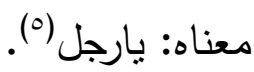

اختلف النحاة في "فل" و "فلة" فقيل هما منقوصان من "فلان وفلانة" بحذف الألف والنون ترخيماً()، خلافاً لابن هثام الذي يرى أنهما ليسا بترخيم، وقيل: هما

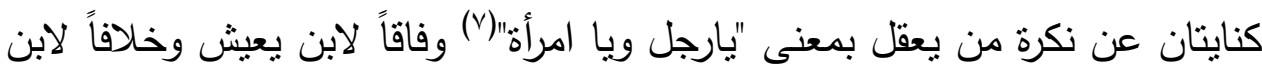
عصفور الذي يرى أنهما كناية عن علم. ويرى المبرد أنَّ "فل وفلة" كنايتان فقولك "يافل أقبل" كناية عن نكرة وليس

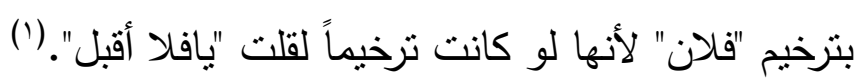
إذن الاتفاق بينهم في كونها كناية وفي كونها ليست بترخيم. ويقول ابن عصفور : "وتقول للمؤنث "يافُلة".(ז) يرى ابن عصفور أن ماذهب إليه الفراء بترخبم "فل عن فلان" مردود وبعضد رأيه بماذهب إليه سيبويه الذي يرى أنه

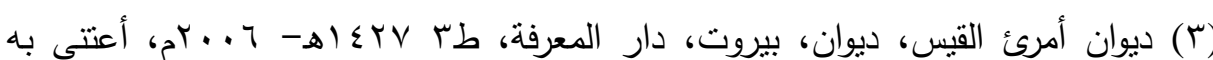

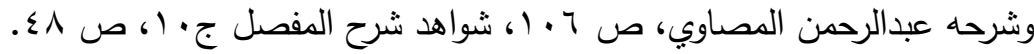

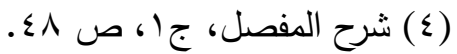

(0) المحرر في النحو، الهرمي، مصر، تحقيق منصور على محمد عبدالسميع،، دار السلام

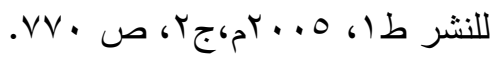

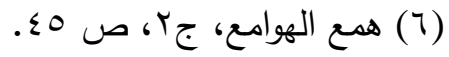

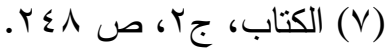

(1) المقتضب، المبرد، بيروت، دار الكتب العلمية، طا، . بـأهـ - 999 (م، تحقيق حسن 
غير مرخم و إنّما هو اسم مختص يقول: "وهو الصحيح ومذهب الفرّاء باطل لأن

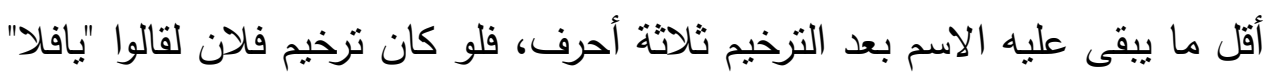

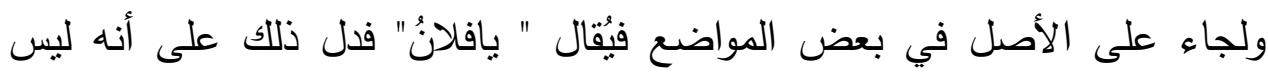

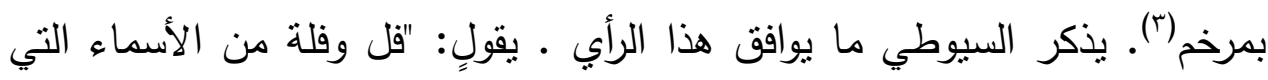

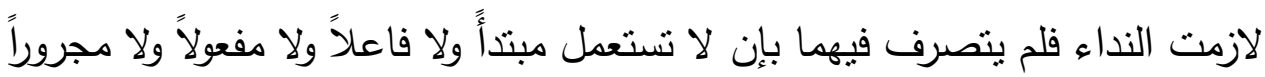

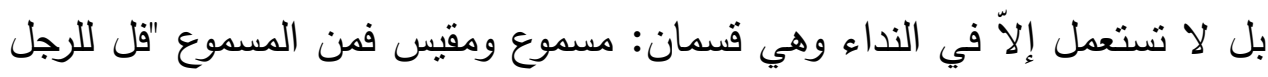

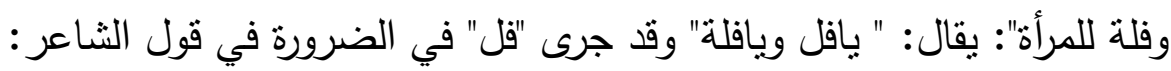

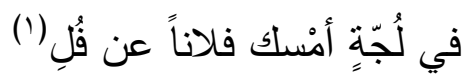
يرد السيوطي على من يدعّى أن الذي ورد في قول الثاعر هو "فلان" صيره

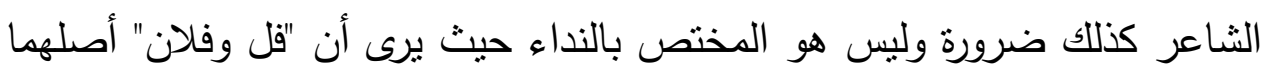

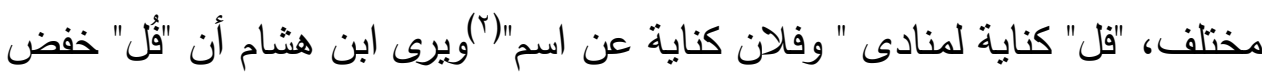
بعن (")كما ذهب إلى ذلك ابن عصفور ويعلل بأن "فل" استعمل في غير النداء

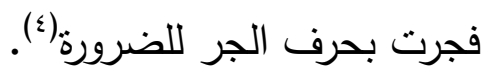
ويلخص ابن عقيل فيقول: "خُص بالنداء أسماء لا تستعمل في غيره إلاّ في ضرورة

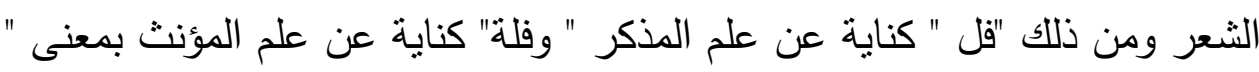
فلان وفلانة" فحصل فيهما الحذف فلا يستعملان منقوصين في غير النداء إلاً في

$$
\begin{aligned}
& \text { (r) شرح جمل الزجاجي، لابن عصفور ، جr، ص V•r. }
\end{aligned}
$$

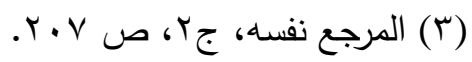

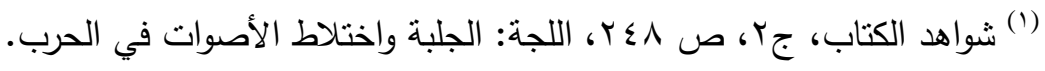

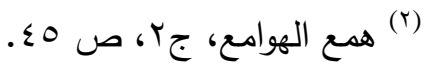

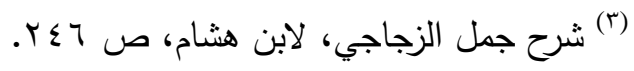

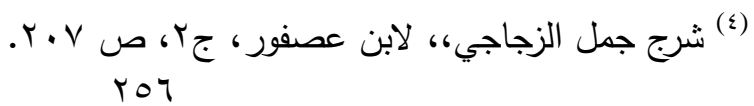




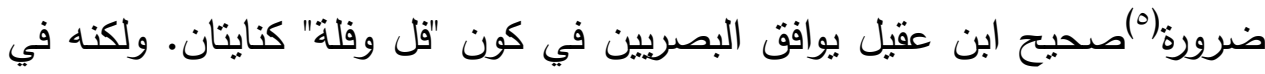

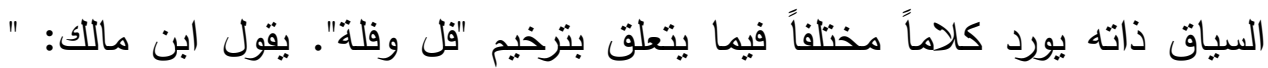

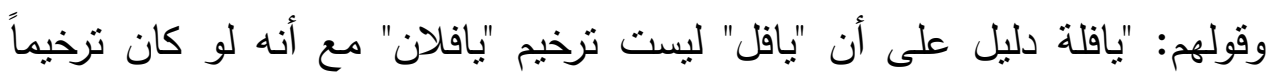

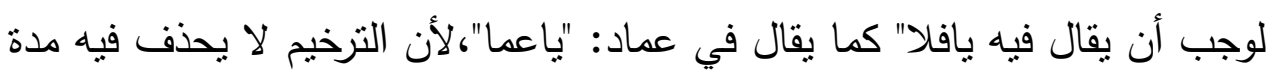

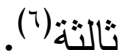

فكما أن الضرورة تبيح وقوع بعض الأسماء في غير النداء كقوله: في لجة أمسك

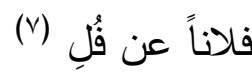

إذن ابن مالك متتاقض فيما ذهب إليه، فهو يوافق البصريين في كون "فل وفلة"

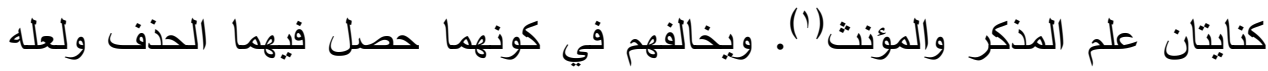

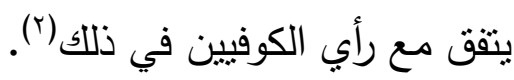
وكذلك ممّا يؤكد على تضارب الروايات التي نسبت لابن فئ مالك زعم أن "فل وفلة"

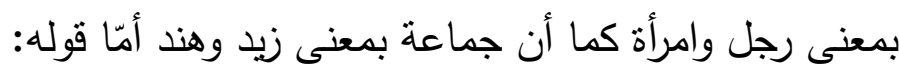

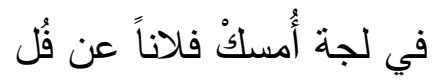
يقول ابن هشام:"هل فُل الخاص بالنداء استعمل مجروراً للضرورة والصواب

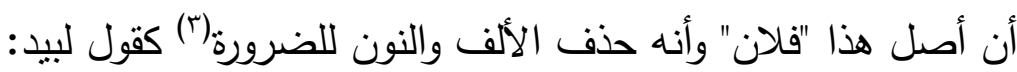

(0) شرح ابن عقيل على ألفية ابن مالك، بيروت، المكتبة العصرية، ط199 ام، تحقيق محمد

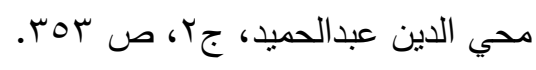

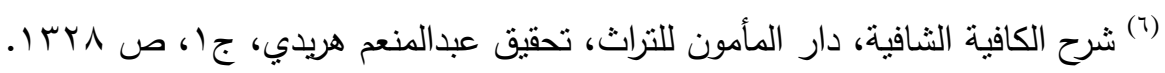

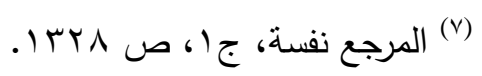

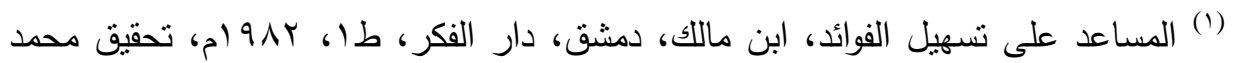

$$
\begin{aligned}
& \text { كامل بركات، جr ص، ص r }
\end{aligned}
$$

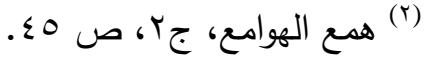

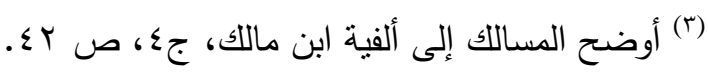
roV 
درسَ المَنا بُمتالعِ فأبانِ * وتَقَادمتْ بالحُبسِ بالسّوبانِ

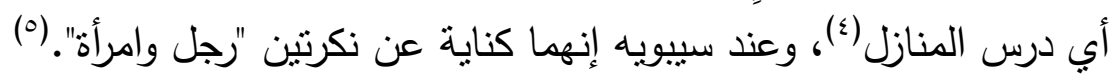

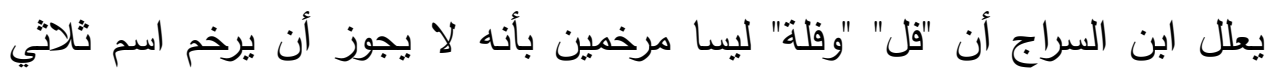

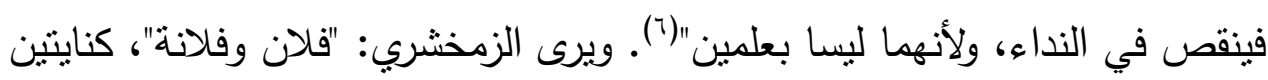

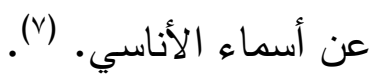
يتحدث ابن الحاجب بقوله: "أعلم أنه قد جاءت أسماء لا تستعمل في غير النداء

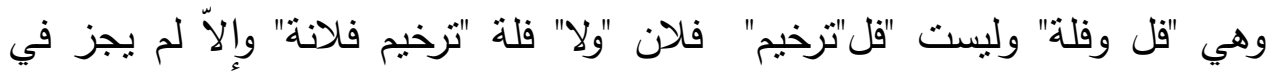

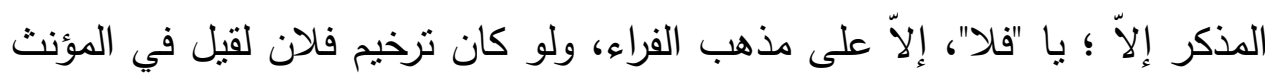
"يافلان" بحذف تاء "فلان" ومن ذلك: يامكرمان ويا نومان ويا لؤمان أى: بان يا كريم

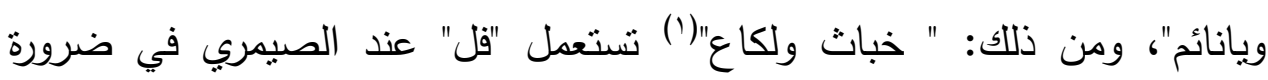

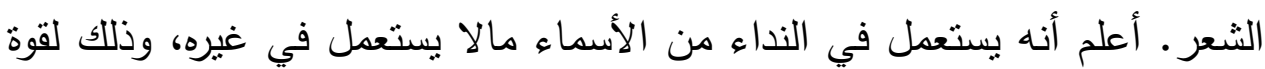

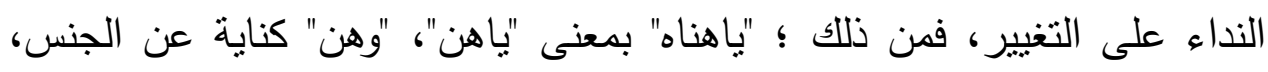

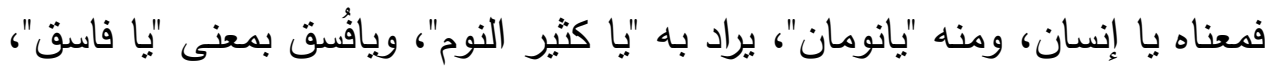

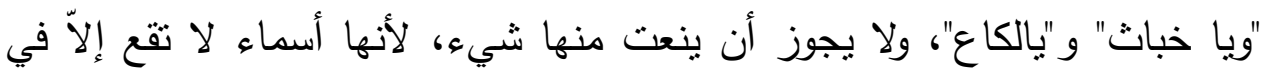

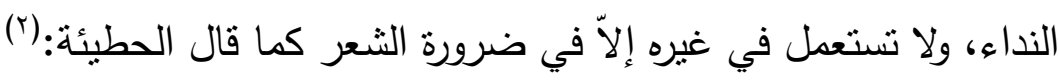

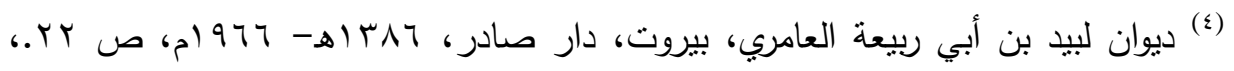

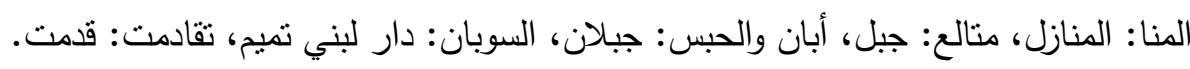

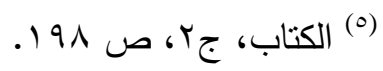

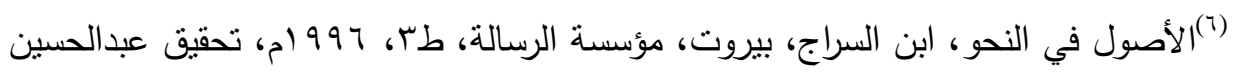

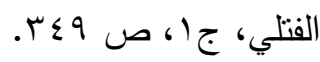

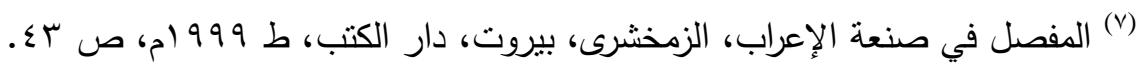

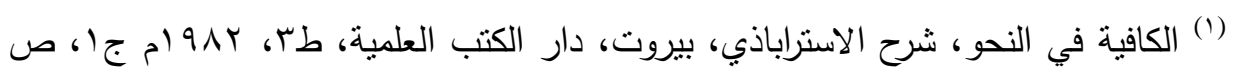




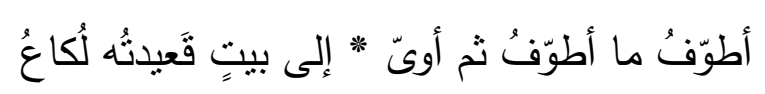

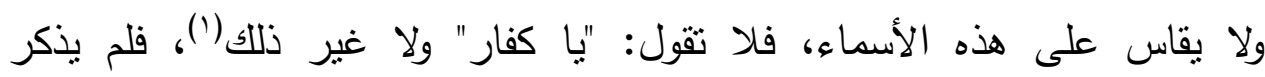

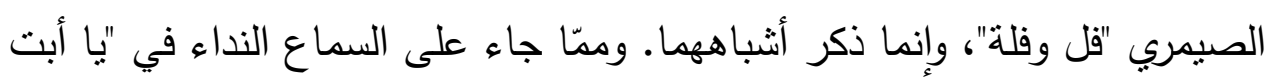
ويا أمة".

يقول ابن هشام: "وممّا لا يستعمل إلاّ في النداء خاصة قولهم: " يا أبت ويا أمة"، لا

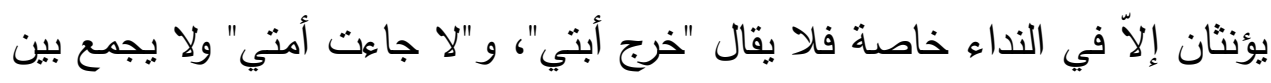

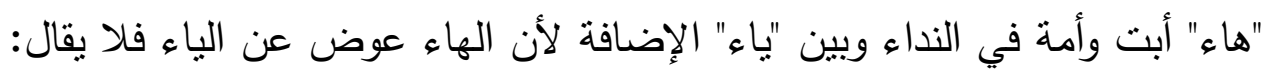

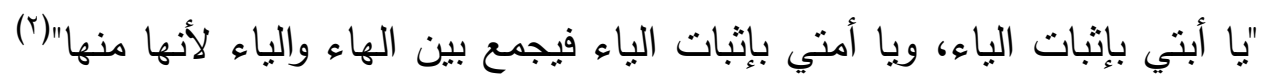

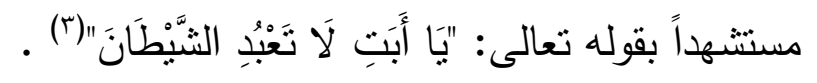
يرى ابن هشام أن "ياأبت" نداء مضاف والهاء في آخره التي تصير في اتصال

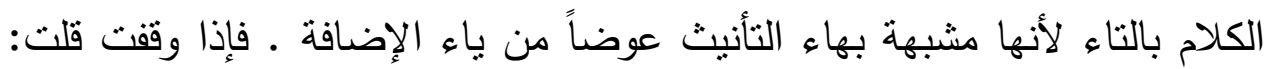

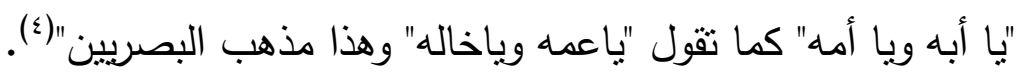

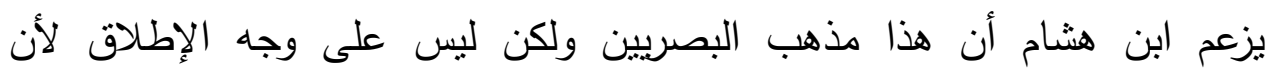

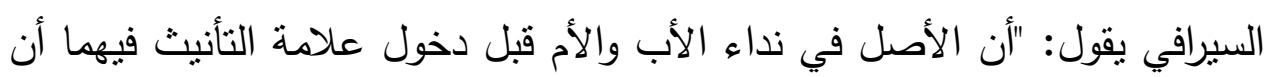

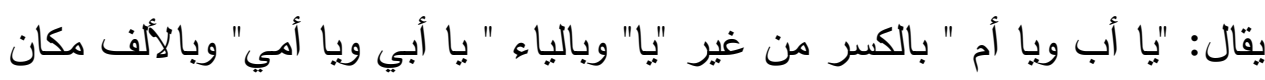

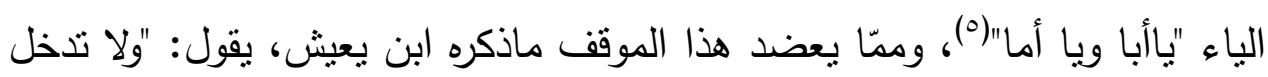

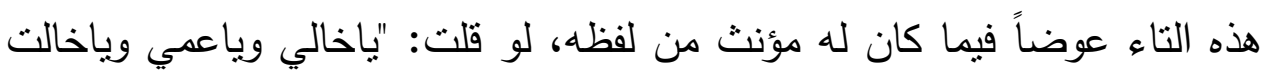

(1) التبصرة والتذكرة،الصيمري دمشق، دار الفكر، طا ب (9 ام، تحقيق فتحي أحمد مصطفى،

$$
\begin{aligned}
& \text { ج)، ص سم r. }
\end{aligned}
$$

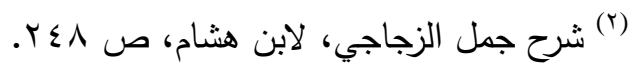

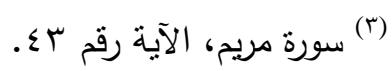

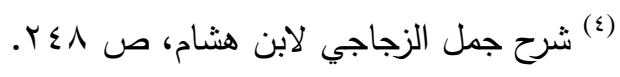

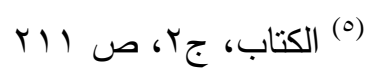


وياعمت" لم يجز لأنه كان يلتبس بالمؤنث فأما دخول التاء على "الأم" فلا إثكال

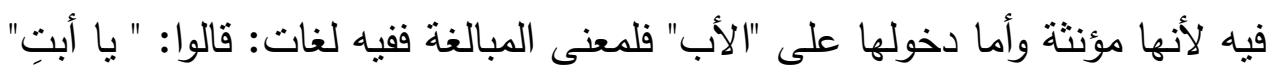

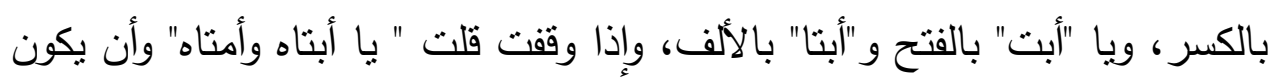

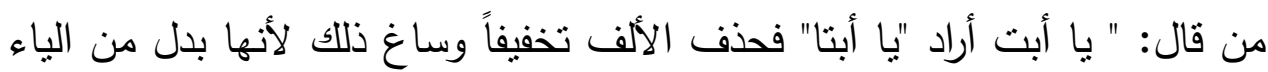
فحذفوها كما تحذف الياء وبقيت الفتحة قبلها تدل على الألف.

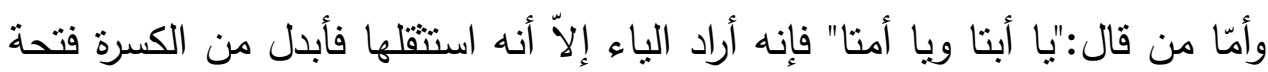

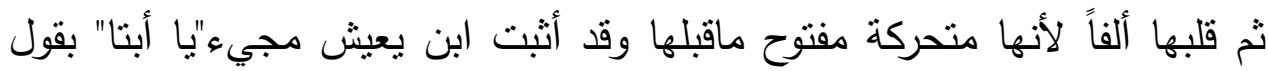

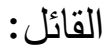

يا أبتا عَلاكَ أو عَساَك (')

ويقول ابن عصفور : "ويجوز أن تقول:" يا أبتا ويا أمتا" فتجمع بين التاء والألف التي أباء

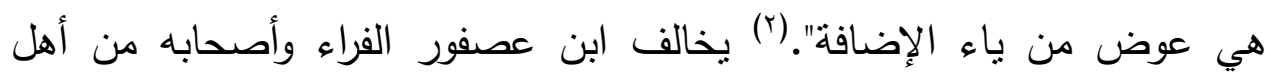

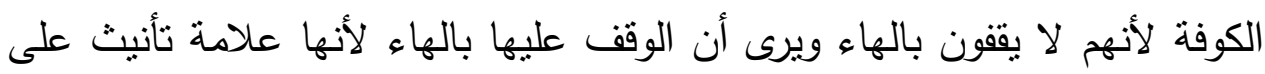

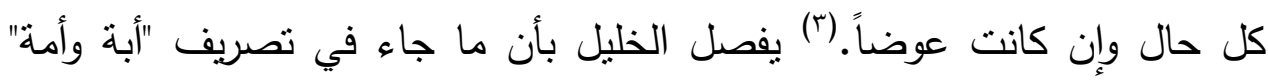
سمع من العرب ويزعم: أنه سمع من العرب من يقول:" يا أمة لا تفعلي" والهاء

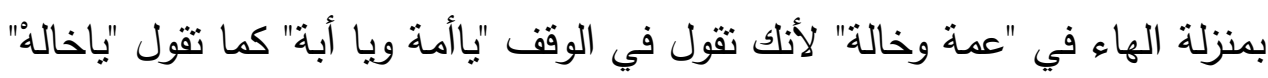

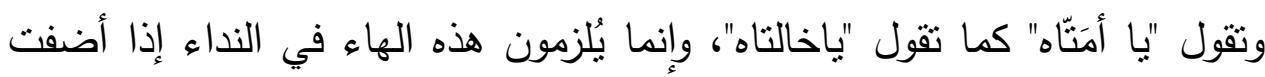

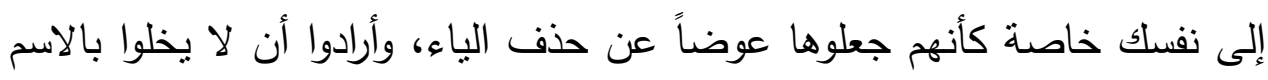

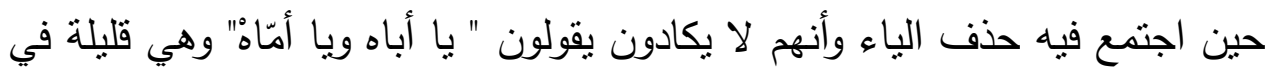

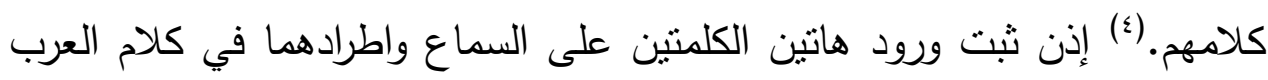

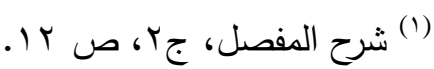

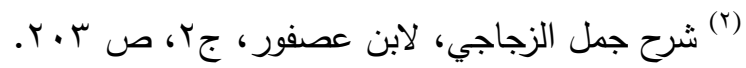

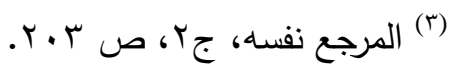

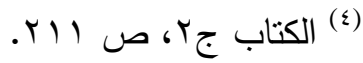

rT. 


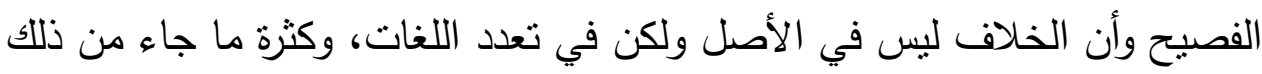

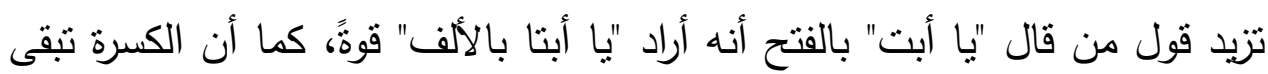

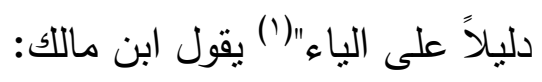

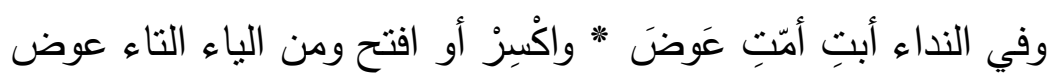

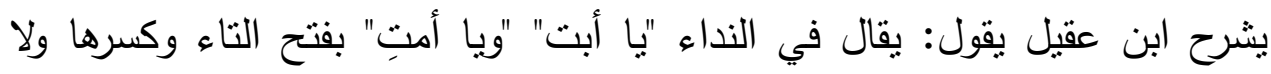

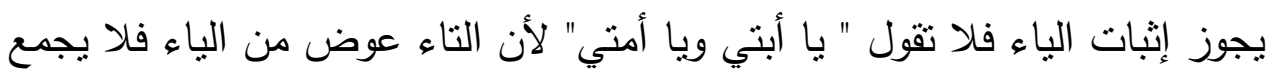

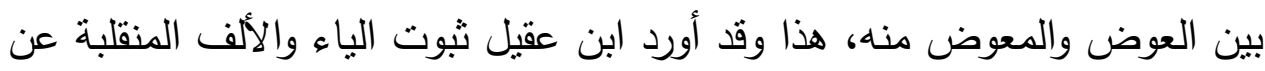

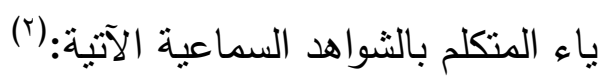
أيا أبتي لا زلت فينا فإنما * لنا أملٌ في العيشِ مادمتَّ عائثا وقول الراجز:

\section{تقولُ بِنْتِ قد أنَى أناكا * با أبتا عالّك أو عَساكا.}

أحياناً تختلف نظرة النحوبين في تحديد المسموع الذي يمكن أن يكون قاعدة وأصل

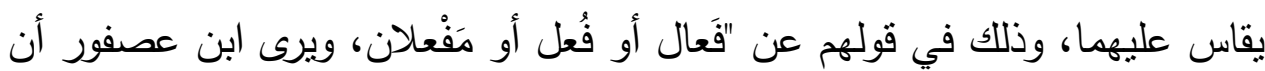

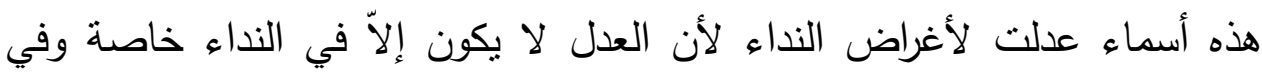

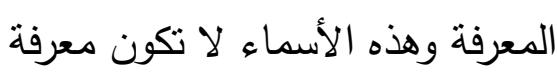

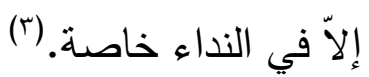
يكرر ابن هشام نفس الرأي ويقول: "أن قولهم: "يا مخبثان ويافُسق ويا كاع ويا

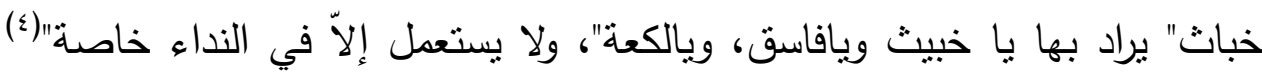

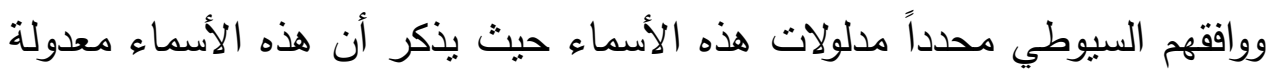

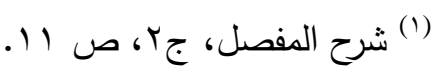

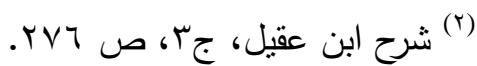

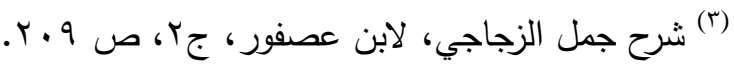

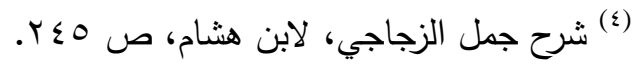


في النداء بعضها مسموع وفيها "مفعلان" في المدح والذم والذي سمع منه ستة ألفاظ

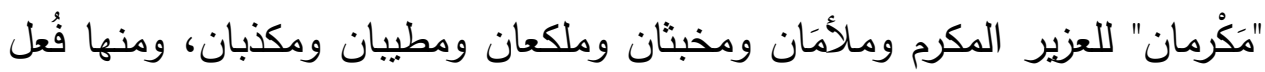

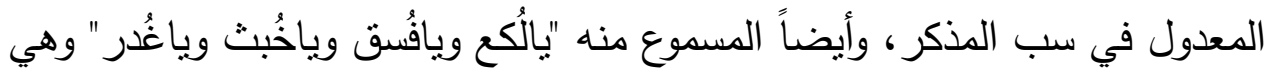

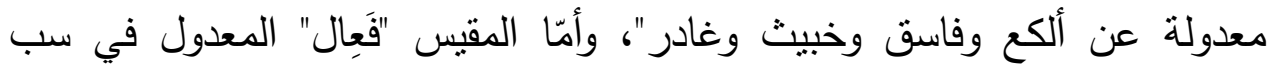

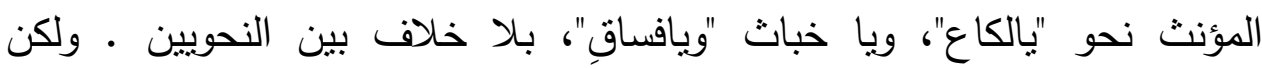

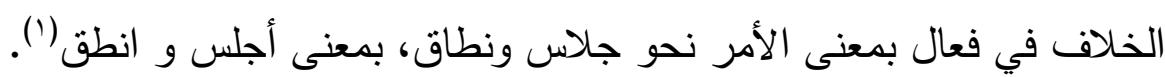

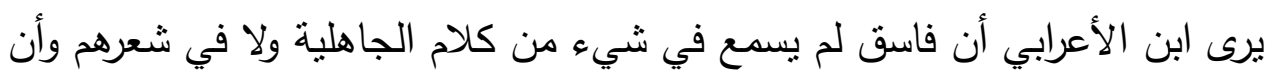

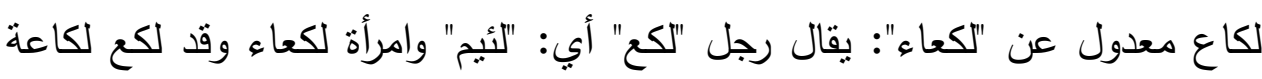

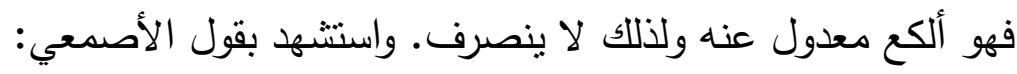

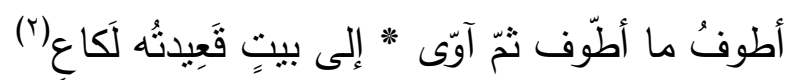
ويخلص ابن يعيش إلى أن "فساق" معدول عن فاسق والفاسق هو الفاجر ، وأصله

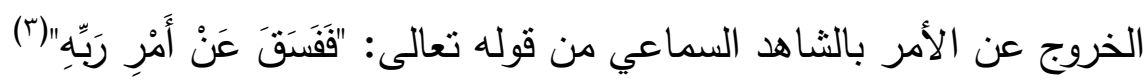
أي خرج عن ذلك (ఓ). ويفصل ابن ماللك بقوله:

وفُلُ بعضُ مايُخص بالنداء" لُومان نومان كذا واطردا

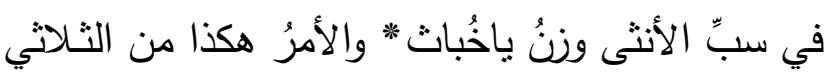

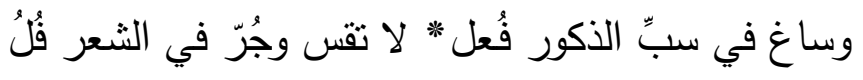

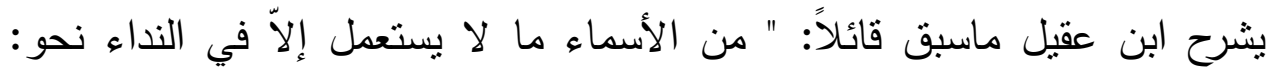

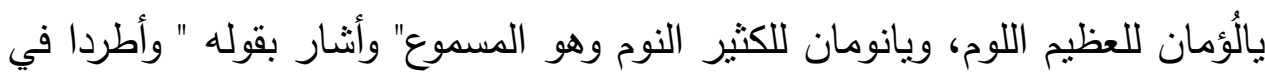

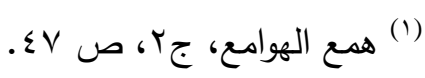

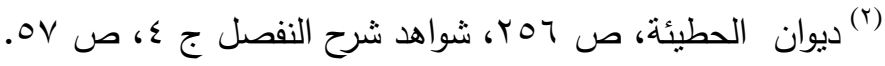

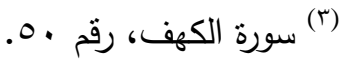

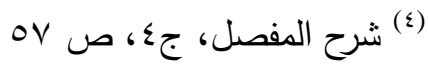


سب الأنثى إلاّ أنه ينقاس استعمال "فعال" مبنباً على الكسر في ذم الأنثى وسبها من

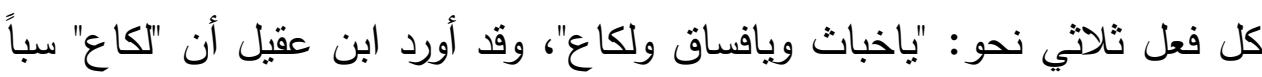
للأنثى وظاهر أنه غير مستعمل في النداء وذللك في قول الحطيئة:

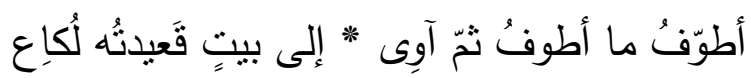

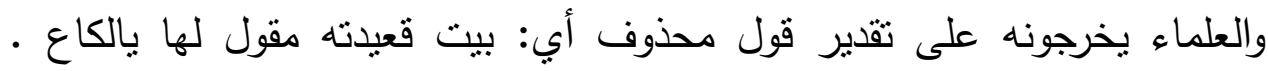

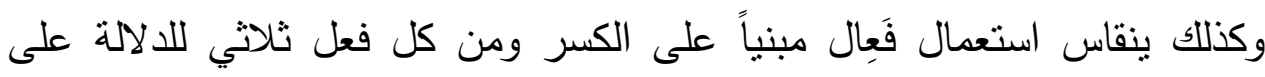

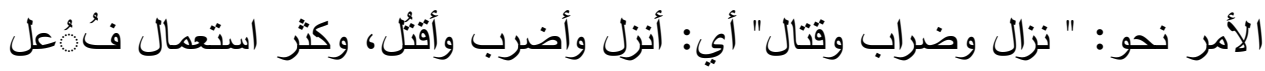

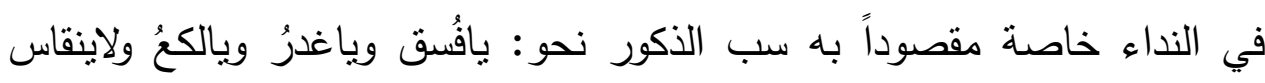
ذللك (').

إذن تجدر الإثارة إلى أن العلماء يتفقون على سماعية هذه الأسماء ماعدا "لُؤمان "

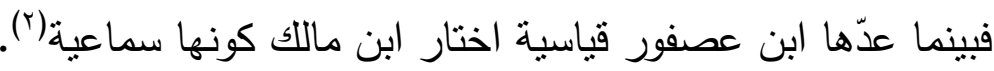

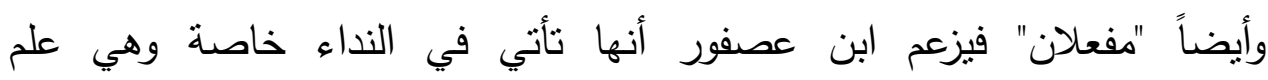

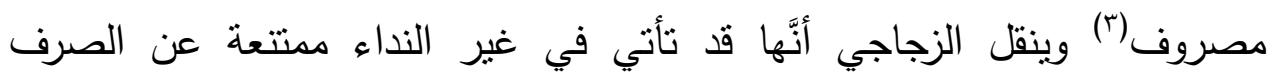

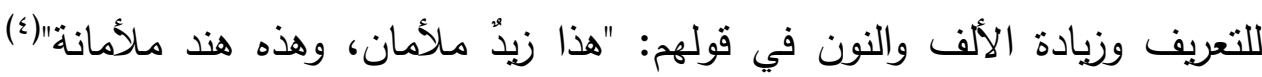
وهنا برى الباحث أن ابن عصفور يتحقق من سلامة بعض الثواهد التي ينقلها الزجاجي.

وممّا سمع في النداء قولهم: "يازيدُ والغلام" بالنصب والرفع، أمّا الرفع فعلى اللفظ، وأما النصب فعلى الموضع.

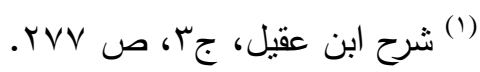

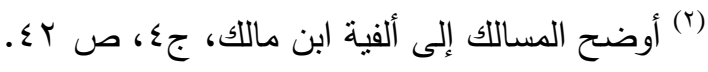

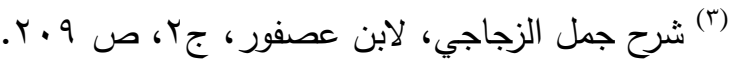

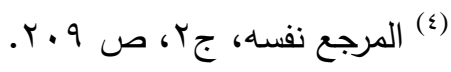


برى ابن هثام أن ذلك جائز سائغ على السماع ويرى أن للعرب لغات في هذا

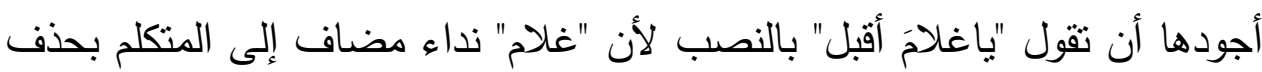

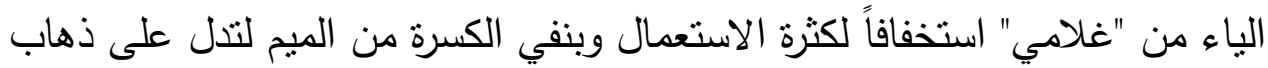

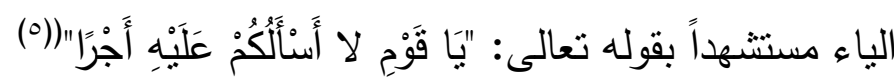

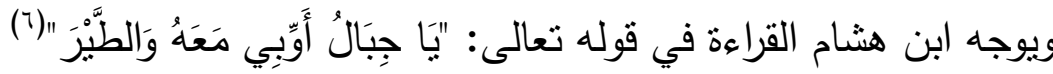

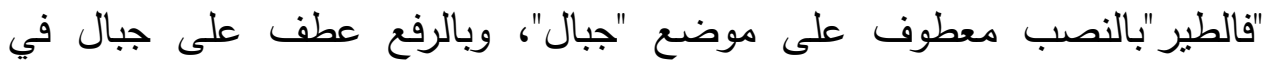

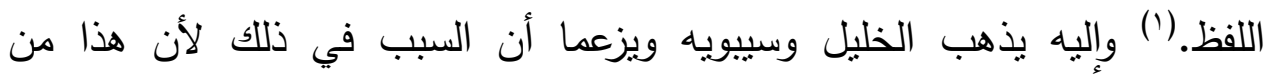

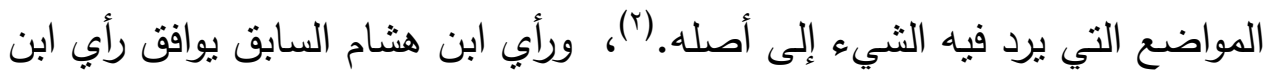

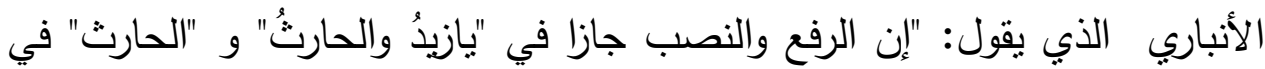

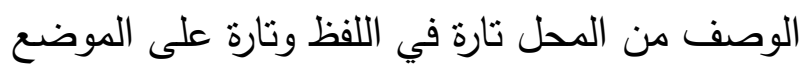

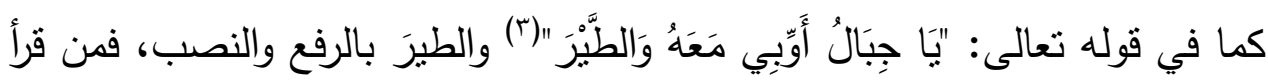

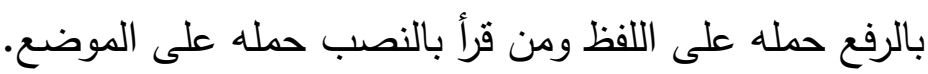

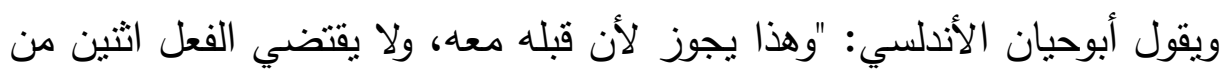

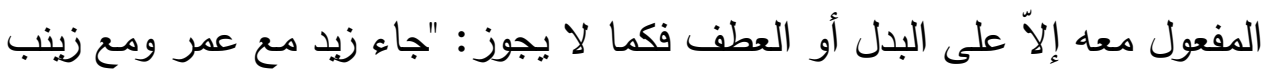

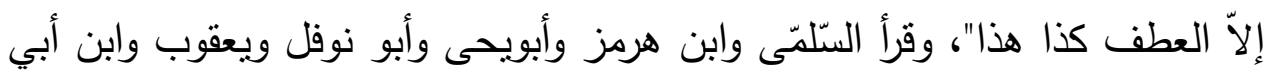

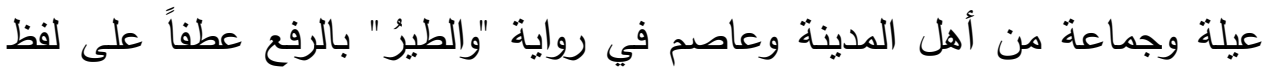

$$
\begin{aligned}
& \text { (1) (سورة هود، } 01 . \\
& \text { (1) سورة سبأ، . 1. }
\end{aligned}
$$

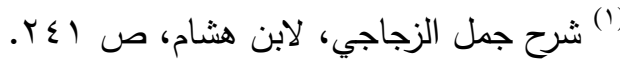

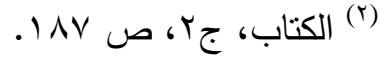

$$
\begin{aligned}
& \text { سورة سبأ، .1. }
\end{aligned}
$$


ياجبال، وقيل عطفاً على الضمير في أوبّي وقال: وسوّغ ذلك الفصل بالظرف،

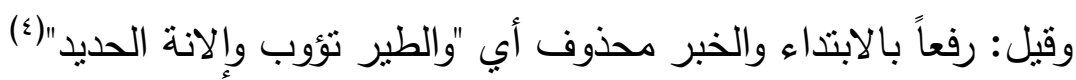

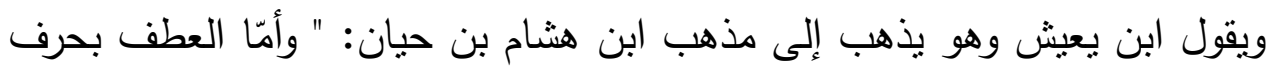

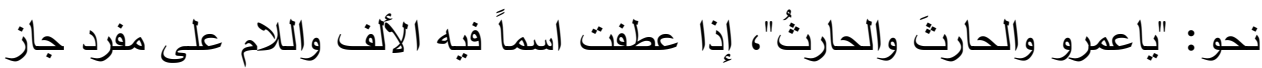
فيه وجهان: الرفع والنصب، نقول في الرفع " يازيد والحارث" وهو اختيار الخليل

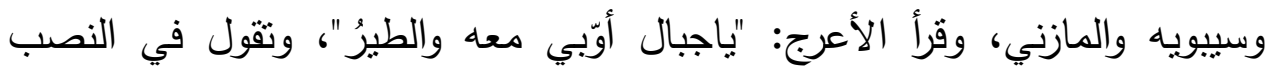

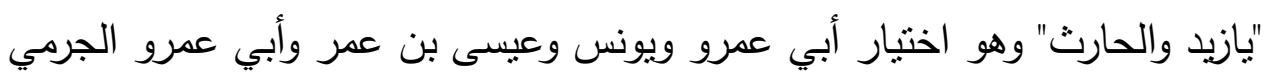

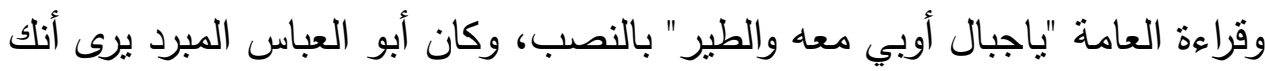

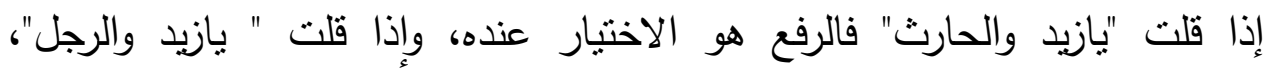
فالنصب هو المختار، وذلك "أن الحارث وحارثاً" علمان وليس في الألف واللام ولثار

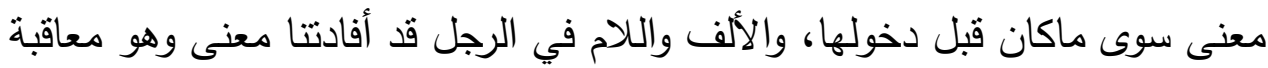

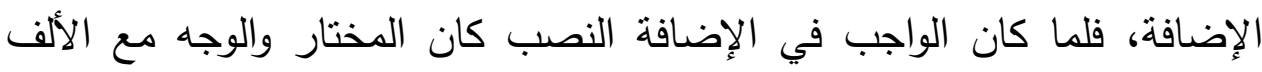

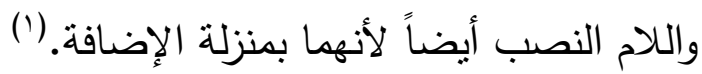

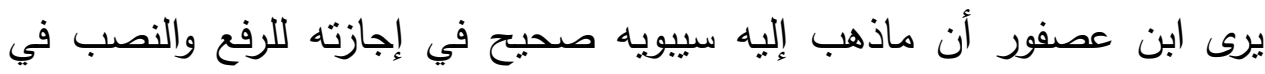

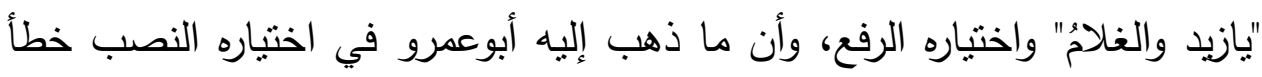

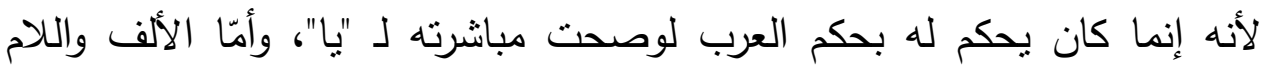

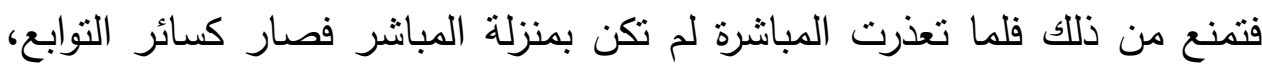

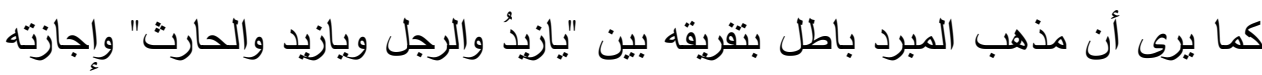
للنصب مع الألف واللام (†). وتحدث ابن ماللك عن المسألة قائلاً:

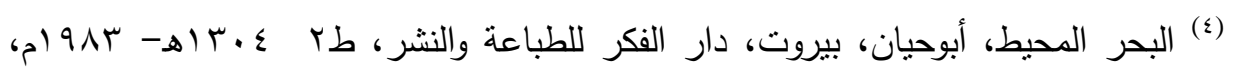

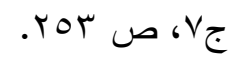

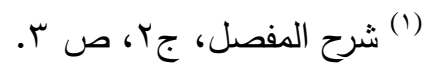

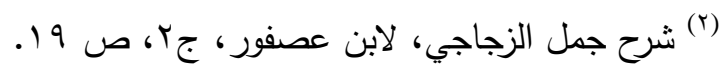
rтo 
وإنْ يكُنْ مصحُوبُ أل مانسقِاً * ففيه وجهانْ ورفعٌ يُنْقِي

ويشرح ابن عقيل: أب: إنما يجب بناء المنسوق على الضم إذا كان مفرداً معرفة

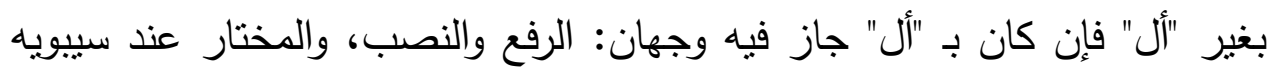

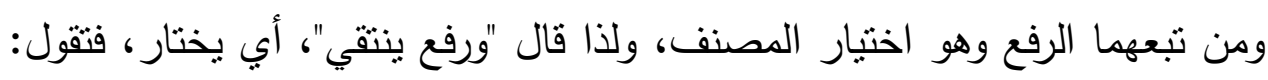

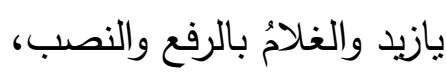

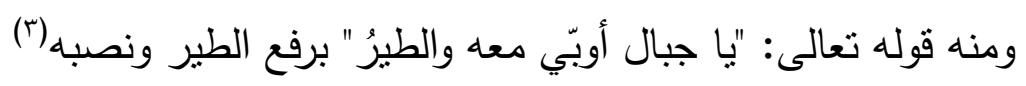

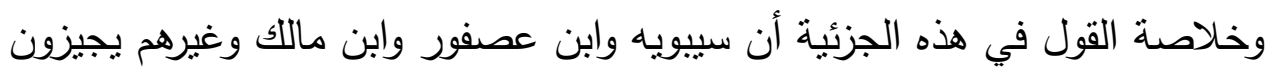

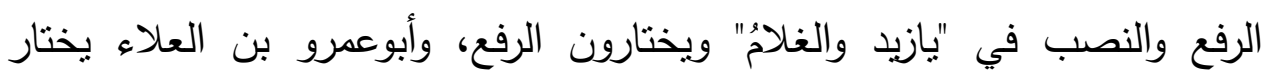

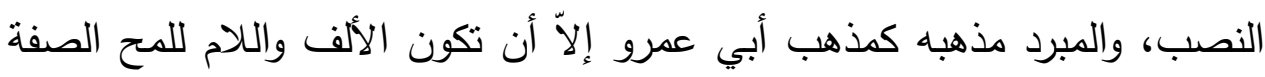
فإنه يختار مذهب سييويه، إلاً أن يكون المنادى نكرة فإنه لا يجيز إلاّ الرفع.

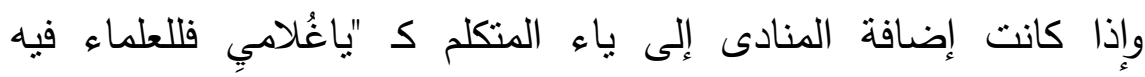
مذاهب:(') يجيز ابن عصفور "ياغلاميَ" سماعاً على الأصل، والثانية "يا غلاميي"،

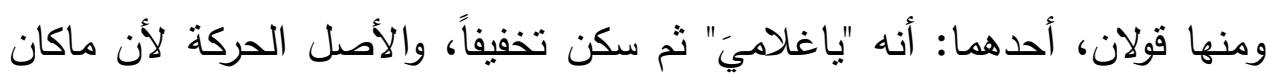

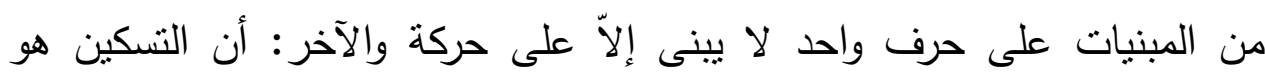

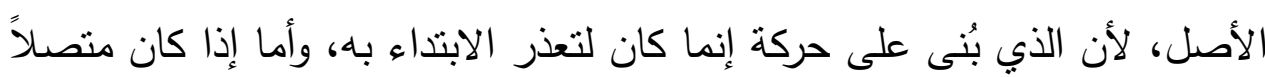

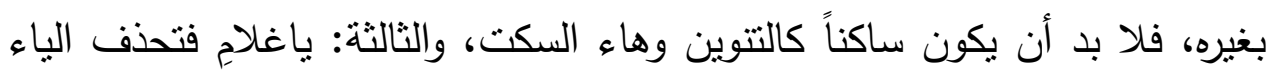

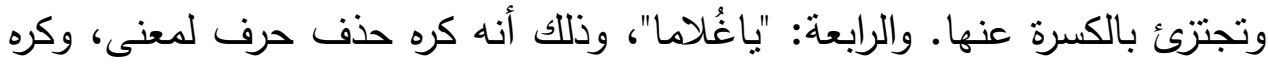

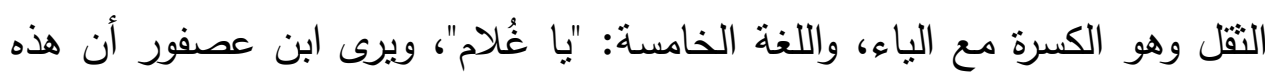

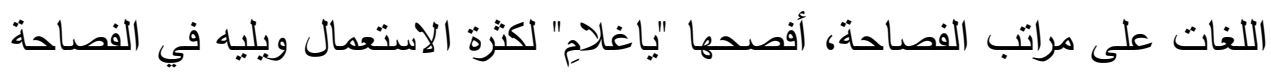

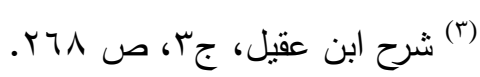

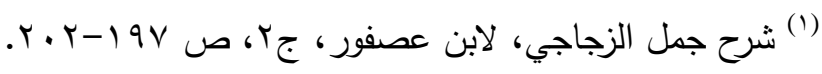

$$
\begin{aligned}
& \text { Tצ }
\end{aligned}
$$


" ياغلامِيْ" لتوسطه، ثُ يليه "ياغِلاما" وياغَلامِيَ وأقلها ياغلامُ لأنه ليس على الياء

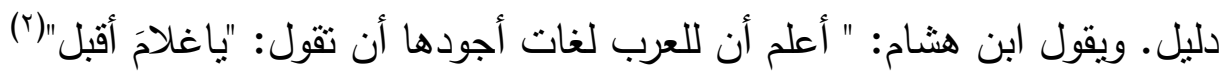

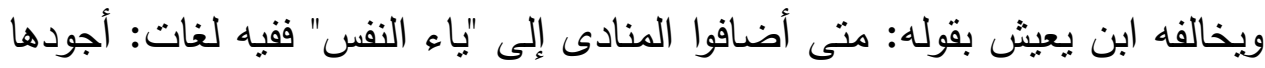

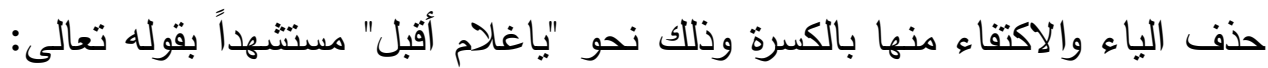

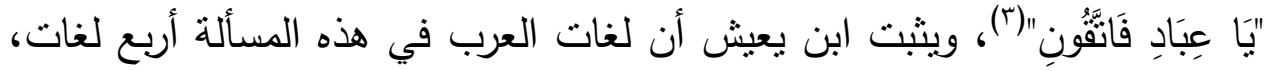
وليس كما ذهب ابن عصفور في أنها خمس لغات،مستخلاً بالثواهد السماعية الآتية:

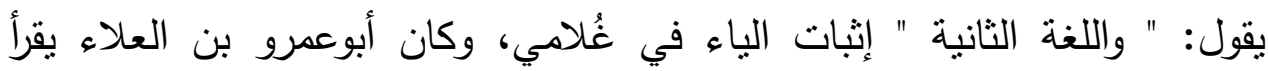

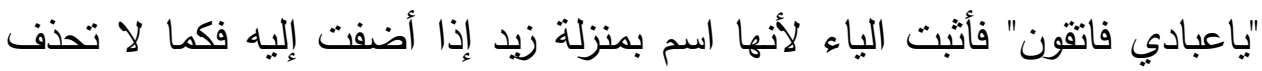

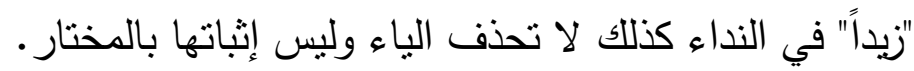
اللغة الثالثة: أن ثقول "ياغلاميَ بفتح الياء وهو الأصل فيها من حيث كانت نظيرة

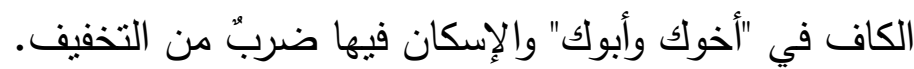

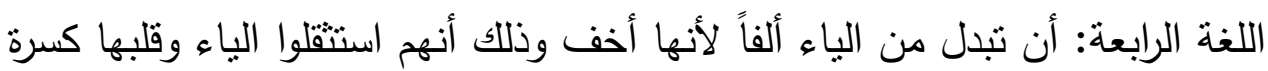
فيما كثر استعماله وهو النداء فأبدلوا من الكسرة فتحة، وكانت الباء متحركة فانقلبت لأباء

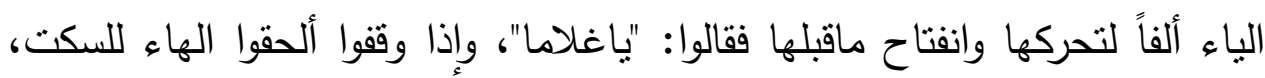
فقالوا: "ياغلاماه"، من يقول باغلاماه قليل لأن الألف بدل من الياء، وليس الاختيار

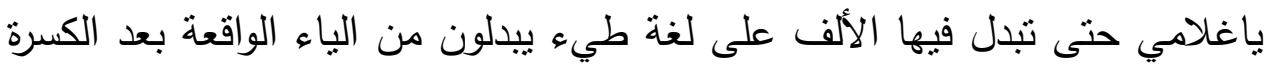

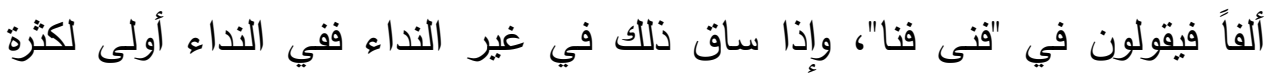

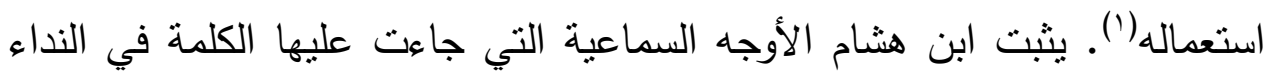

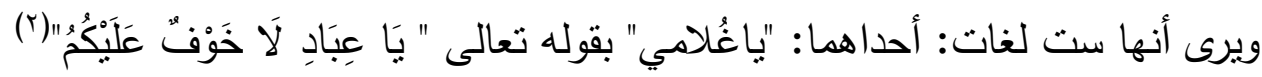

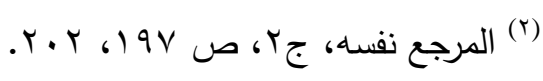

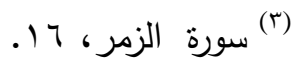

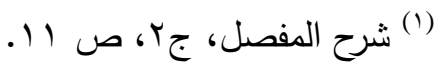

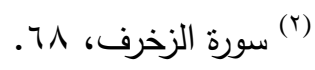


الثانية: " ياغلام" بحذف الياء الساكنة، وإبقاء الكسرة دليلاً عليها: قال تعالى: "ياعباد

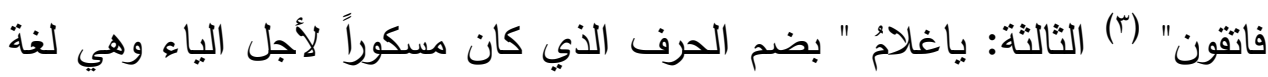

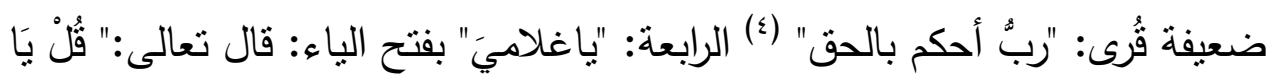

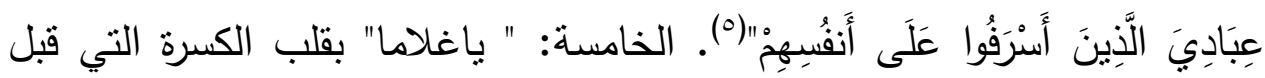

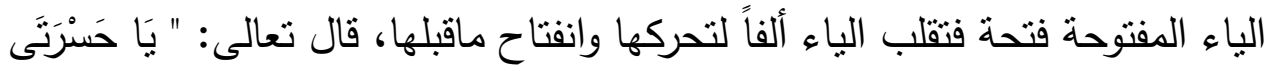

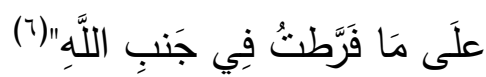

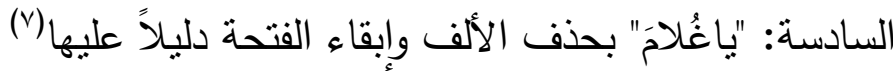
يقول ابن مالك:

واجْعلْ مُنادى صَحْ إن يُضيف ليا * كعبدِ عَبدي عَبْدَ عَبْدا عبدياً

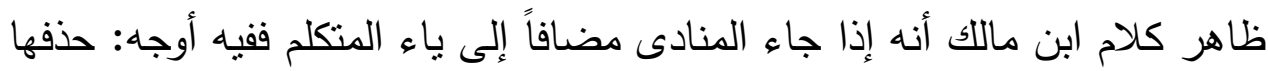

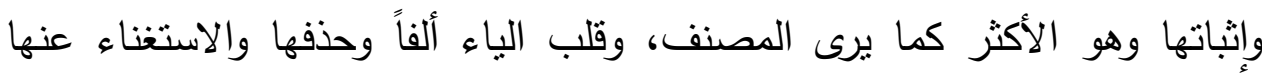

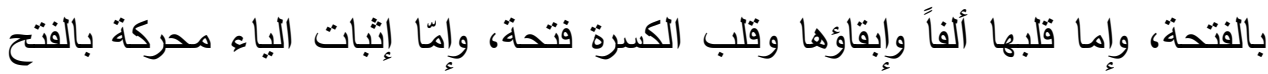

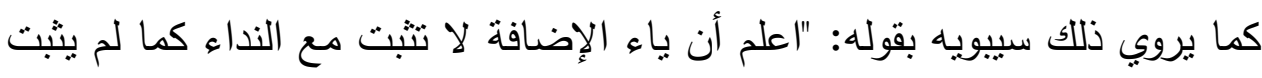

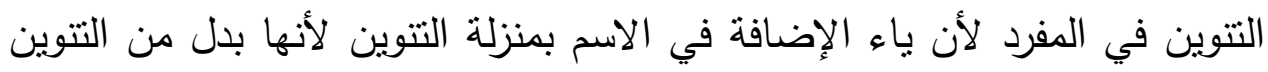

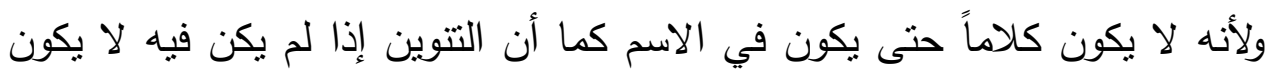

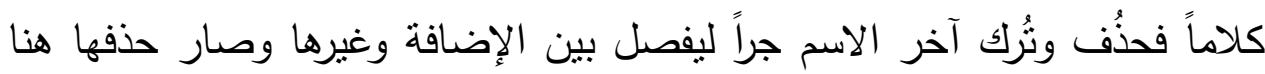

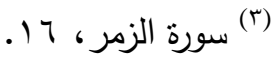

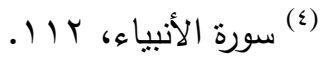

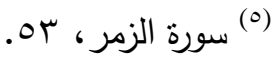

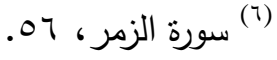

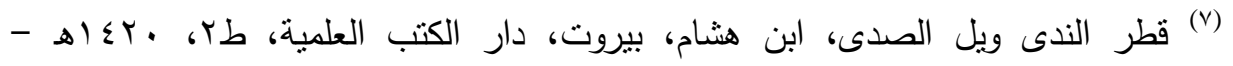

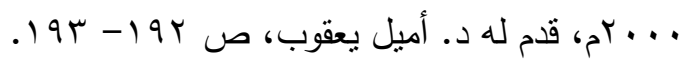

$$
\begin{aligned}
& \text { rTA }
\end{aligned}
$$


لكثرة النداء في كلامهم حيث استغنوا بالكسرة من الياء، ولم يثثتوا حذفها إلاّ في النداء.

ولم يكن لبس في كلامهم لحذفها، وكانت الياء حقيقية بذلك لما ذكرت للك إذ حذقوا

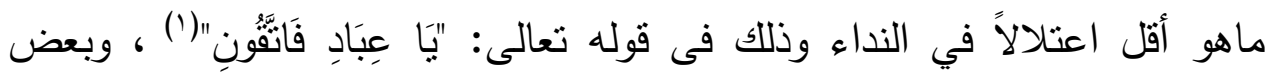
العرب يقول "ياربُّ أغفر لي" و " ياقومُ لا تفعلوا" وأعلم أن بقيان الياء لغة في النداء في الوقف والوصل تقول: " ياغلامي أقبل، وكذللك إذا وقفوا"(؟) يرى ابن عصفور أن الحذف في النداء شبيه بالترخيم في غير النداء وكلاهما ورد به السماع مستشهداً بقول الثاعر:

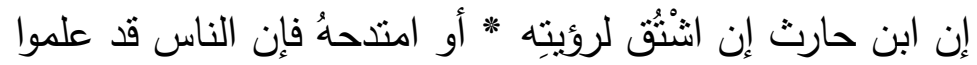

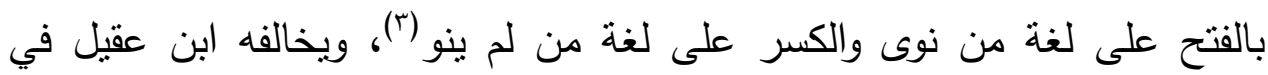
سياق التعبير وفي حركة الكلمة بعد الحذف أو الترخيم، فيعبر عن الأولى بلغة من ينتظر الحرف وعن الثانية بلغة من لا ينتظر الحرف، ويرى أيضاً في لغة من ينوي تزك الباقي بعد الحذف على ماكان عليه من حركة أو السكون. فتقول في جعفر

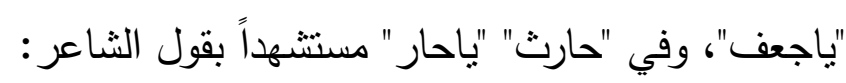

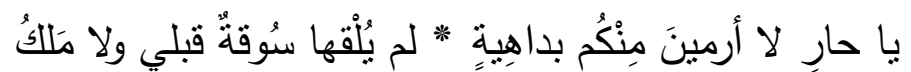
وإذا رخمت على لغة من لا ينو أي "لا ينتظر" عاملت الآخر بما يعامل به لو كان

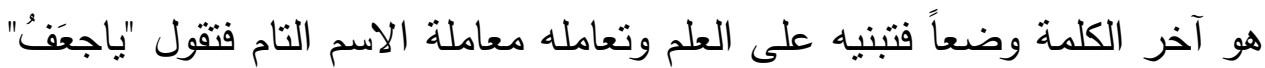
"وياحارُ "، وفي "ثمود" بلغة من بنتظر "ياثموْ" بواو ساكنة، وعلى لغة من لا ينتظر :

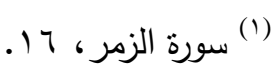

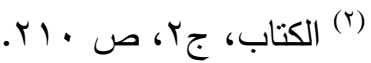

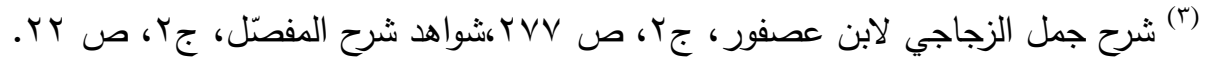


يا ثمي فتقلب الواو والضمة كسرة لأنك تعامله معاملة الاسم التام، ولا يوجد اسم

معرب آخره واو قبلها ضمة إلاّ ويجب قلب الواو ياءً والضمة كسرة. (')

يورد ابن الأنباري الرأي نفسه يقول: " إن المرخم يبنى على الضم ويجوز أن يبقى

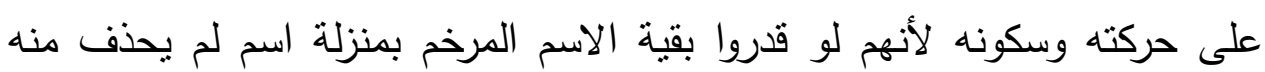
شيء فبنوه على الضم نحو: "ياحارُ، وبا مال" (؟) وبوافقه ابن هشام على حذف الف الآخر وترك ما قبل المحذوف على حركته، ويرى أن الوقوف على الكسر أفصح لأنّه الأكثر في كلام العرب، (ז) وياحار بالكسر ، باسقاط التاء من آخره وترك الراء

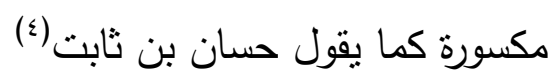

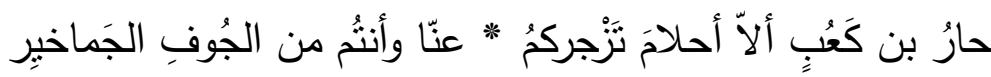

أراد باحارث فاسقط حرف النداء لقرب المنادى منه وحذف الثاء من حارث

للترخيم(*). وهذا بالطبع وفاقاً لما ذكره ابن عصفور في مشابهة الحذف في النداء والترخيم في غير النداء. ويقول السيوطي: وفي المرخم لغتان: الانتظار وهو نية المحذوف وترك الانتظار ، وهو عدم نيته، والأول أكثر استعمالاً، وأقواهما في النحو، وهئ وجاء عليه ماقرئ: "ونادوا يامالِ" وقول الثاعر : ياحارِ لا أرمين مِنْكُ بداهيَة.

$$
\begin{aligned}
& \text { (1) شرح ابن عقيل، جr، ص rqهr. }
\end{aligned}
$$

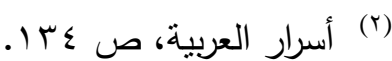

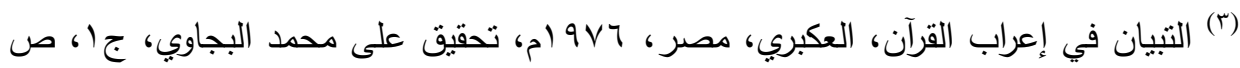

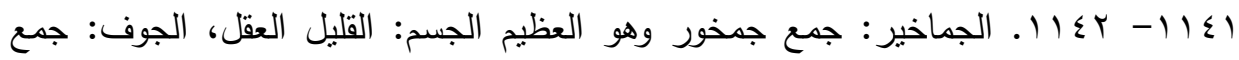

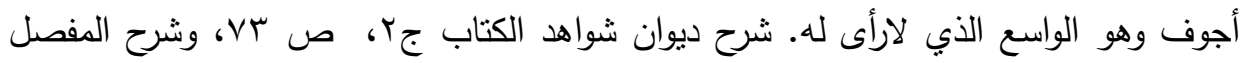

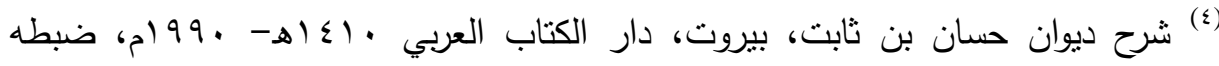

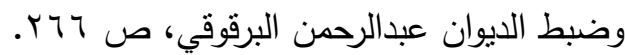

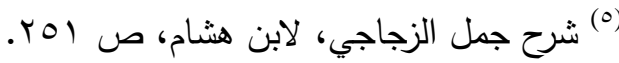
rV. 
ثُّ إذا انتظر فلا يغير مابقى على حركته وسكونه، فيقال: ياجعفَ، ولا يُعل فيقال في ثمود "ياثمو".(') لعل اختلاف الثاهد السماعي في قراءة الآية الكريمة دليل على اعتماد السماع في الأرث اللغوي الممتد أصلاً في توجيه القاعدة النحوية، حيث يورد العكبرى أن الوقوف على الكسر قرأ به النبي " صلى الله عليه وسلم"(؟) ، وأورد أبو حيان قراءة الكسر ونسب قراءة الضم "يامال" بالبناء على الضم إلى أبي السرار الغنوي، بجعله له اسماً على خياله.(ז) يذكر سيبويه جملة الوجوه التي يكون عليها الحرف بعد الحذف ولعله يختار الكسر وذلك واضح من سياق كلامه ـ يقول: " وأعلم أن الحرف الذي يلي ما حذفت ثابت على حركته التي كانت فيه قبل أن تحذف، إن كان فتحاً أو كسراً أو ضماً أو وقفاً نحو قولهم "في ياحارث: ياحار"(؛) يذهب ابن يعيش إلى اختيار الضم والكسر معاً ويفصّل في أنواع المرخم. حيث يرى أن المرخم مفرداً أو مركباً على ضربين: أحدهما: ما يحذف منه في النداء إلاّ حرفاً واحداً نحو : قوللك: "في حارث"، ويجوز فيه الضم والكسر وذللك وفقاً للآتي:

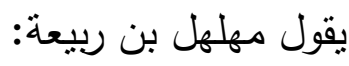

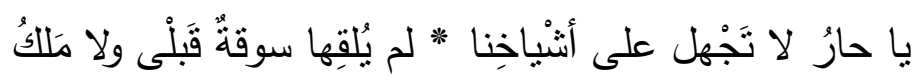
ينشد بكسر الراء وضمها، وكما سمع ذلك في قراءة بعضهم قارئاً "ونادوا يا مال ليقض علينا ربك"، فقال ما أثخل أهل النار على الترخيم، فقال: ذلك لأنهم لا يقدرن على التلفظ بتمام الكلمة لضعف قواهم. والثاني: ما يحذف منه في الترخيم حرفان وذلك شيئان أحدهما: ما كان في آخره زائدنان زيدتا معاً، فمن ذلك ما كان في آخره ألف ونون نحو "مروان - يامرو"، وأمّا حرف صحيح ومدة قبله وذلك في

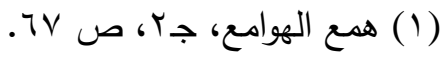

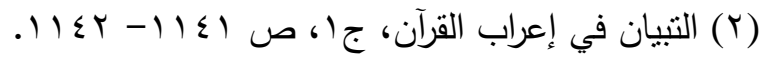

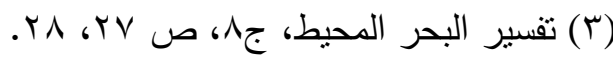


مثل منصور ، فما كان آخره حرفاً أصلياً وقبله حرف مد زائد فإنك تحذف الأصل وما قبله من الزائد معاً وتجريهما معاً مجرى الزائدين إذا بقى بعد حذفها ثلاثة أحرف هره نحو: "عمار ومنصور" تقول: " يامنص وياعم" وذلك لأنهما جريا مجرى الزائدين وذلك من حيث أن الأصل يحذف للترخيم لأنه طرف كما يحذف الزائد الثاني من

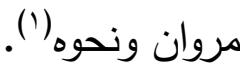

يوافق ابن الأنباري رأي بعض الكوفيين بجواز الترخيم في الأسماء على الإطلاق (؟).

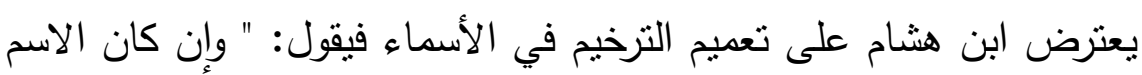
على أربعة أحرف وكان ثالثه الياء الزائدة أو الواو أو الألف ورخمته لم تحذف الواو، ولا الياء ولا الألف في ترخيم "ثمود" .. " ياثمو " لأن الثثلاثة أقل الأصول فيبقى الاسم على أقل من ثلاثة أحرف ولا يحذف منه شيء لأنك تبقى الاسم على أقل من ثلاثة

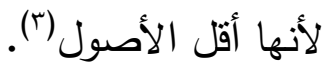
يجيز سييويه مايحذف منه في الترخيم حرفان لأنهما زيادة واحدة بمنزلة حرف واحد

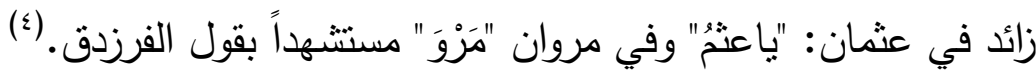

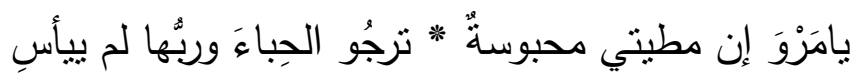

معتبراً أن الألف والنون حذفتا للزيادة وكون الاسم ثثلاثياً بعد حذفهما.(*)، كما يجيز ذلك ابن عصفور ولكنّه يعترض على الفرّاء في أن كان الحرف الثالث ساكناً مثل بلث

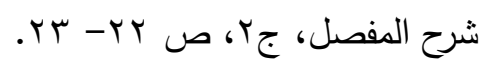

الإنصاف في مسائل الخلاف بين النحوبين البصريين والكوفيين، تأليف كمال الدين أبي

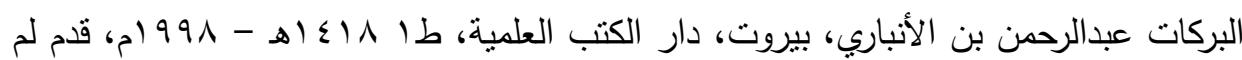

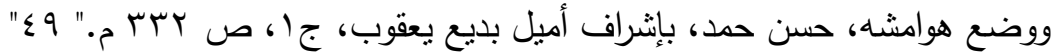

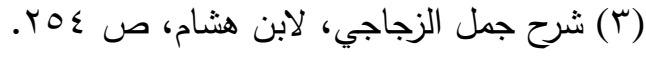

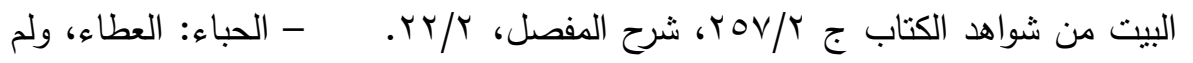


"هرقل"، فيرى الفرّاء يجوز ترخيمه على لغة من "لم ينو تقول "هرق" وعلى لغة من نوي تقول "ياهَر"، حيث يرى ابن عصفور هذا فاسد من غير وجه لأن فيه رد الاسم إلى حرفين وذلك لم يسمع من كلام العرب.(')، كما يرى ابن عصفور في ترخيم المتحرك الوسط "ياحَكَّ" وياعُمُ في ترخيم حكم وعمر هذا لم يسمع والقياس يدفعه لأنه تغيير لا يُحتاج إليه لأن الترخيم أولاً غير جائز (؟). وبذهب إلى منعه الكسائي لأنه لم يرد به سماع ولا يقبله قياس ووافقه السيوطي(r). ولعل هذا كله يوافق ما ذهب إليه ابن هثام في معرض رده على من يرى أن الترخيم في الأسماء على بلى الإطلاق. يرى السيوطي أن الحذف في "حارثة" بالتاء هكذا ورد به السماع فى:

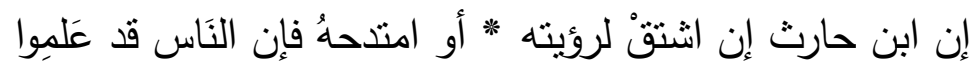

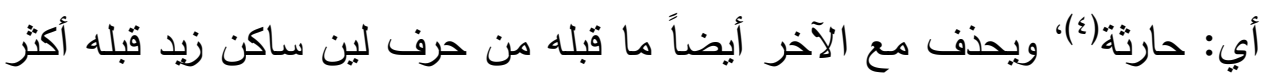
من حرفين وحركة تجانسه سواء كان الآخر صحيحاً أصلياً أم زائداً أم حرف علة بشرط ألاّ يكون هاء تأنيث فيقال في "منصور "ومروان وأسماء "يامنْص وبامَزْو وبا

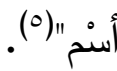
يقول ابن هشام في ترخيم الخماسي نفس الرأي " في ترخيم ما كان قبل آخره" ياء أو

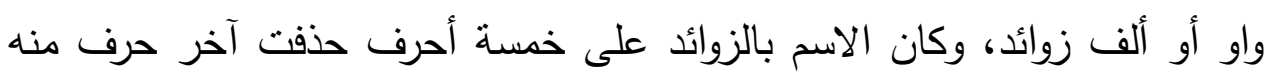
وحذفت منه الزوائد في ترخيم "مسعود" مَنْعُ، فإذا رخمت اسماً على خمسة أحرف آخره ألف ونون زائدنان حذفتهما جميعاً للترخيم لزيادتها واستغنى الاسم عنهما لزيادتهما وذللك مثنل:

$$
\begin{aligned}
& \text { (1) شرح جمل الزجاجي، لابن عصفور، جr، ص YIV. }
\end{aligned}
$$

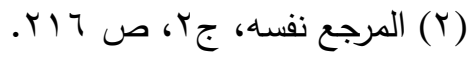

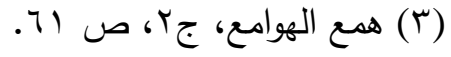

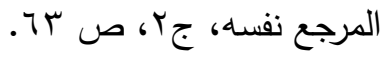




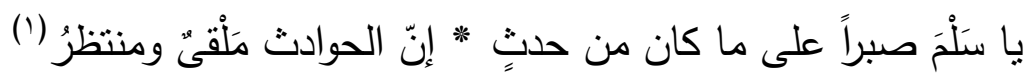
أراد سلمان، وفي مروان "بامَرْوَ".

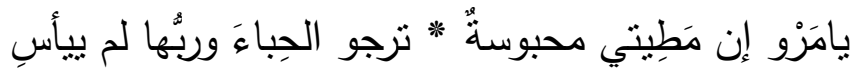

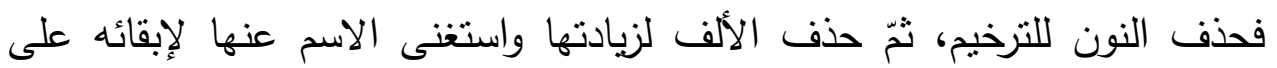

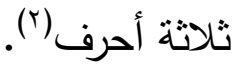

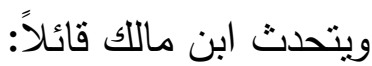

ومع الآخر أحذف الذي تلا * إن زيد ليناً ساكناً فكملا

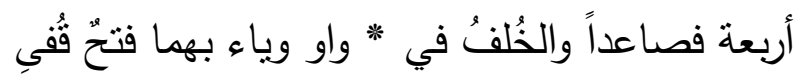
ويشرح ابن عقيل ما سبق بقوله: يجب أن يحذف مع الآخر ماقبله إن كان زائداً ليناً

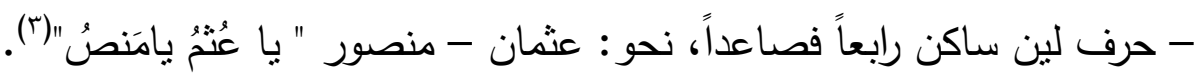

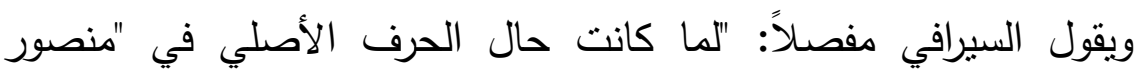
وعمار" قد وجب حذفه لأنها طرف الأسماء صارت هذه الحروف الأصلية في الحذف كالزائد الثاني من الزائدين بمنزلة الزائد الذي قبل الحرف الأصلي وقد ساوى

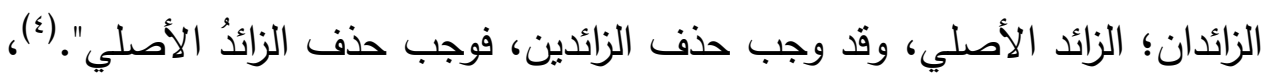
يرى الأعلم أن "أسماء": عند سيبويه "فعلاء" لأنه جعل في آخرها زيادتين زيدتا معاً فحذفتا في الترخيم في مروان معاً وشاهده السماعي قول الثناعر :

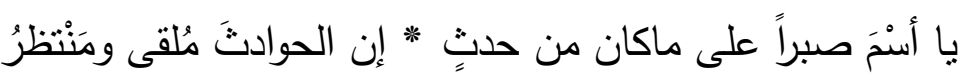

$$
\begin{aligned}
& \text { (1) من شواهد الكتاب، جr، ص rON. }
\end{aligned}
$$

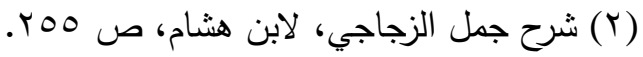

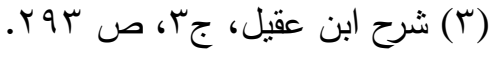

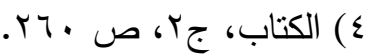


"أسحَ": ترخيم أسماء(")، هذا فيما كان آخره ألف التأنيث "ياحمر وياصحر"، با "أسم"

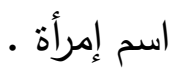

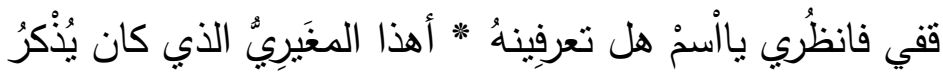

$$
\text { يعني: أسما: (؟) }
$$

أمّا ماكان آخره تاء الثأنيث يروى ابن الأنباري: أنه يجوز ترخيم مافيه علامة التأنيث، لأنها بمنزلة اسم ضم إلى اسم، وليس من بناء الاسم فجاز حذفها

$$
\text { معتبراً أن "حارث" ترخيم "حارثة". }
$$

$$
\text { وإن ابن حارث وإن انشتق لرؤيته }
$$

يريد: " ابن حارثة"(") ويذهب السيوطي إلى ترخيمه على وجه لروئه

الإطلاق، وابن عصفور يمنع ذلك كما يزعم أنه لا يجوز ترخيم "قلمعة" لأنه كناية

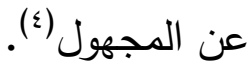

كما أجاز سيبويه حذف ما قبل هاء التأنيث نحو: "عثمانة باعُثم"(() لأنه ورد به

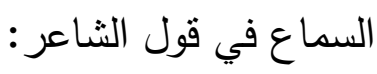

$$
\text { أحارِ بن بدر قد وليتَّ ولاية }
$$

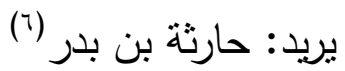

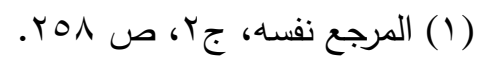

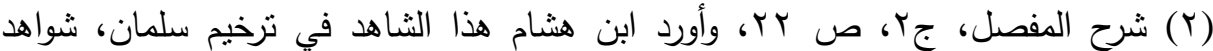

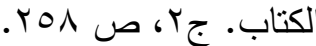

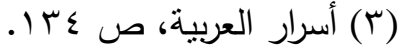

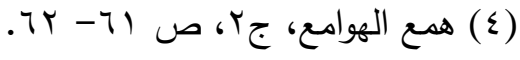

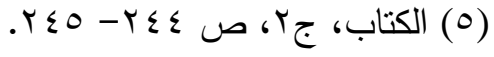

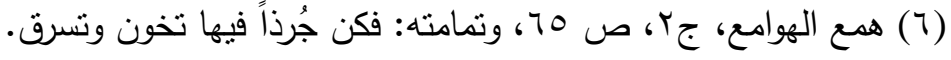


ويروي ابن هشام ذلك ويقول في ترخيم عائشة "ياعائش"(V)

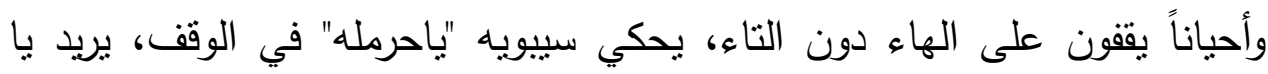

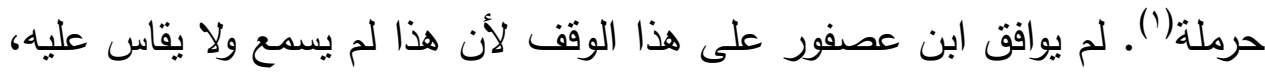

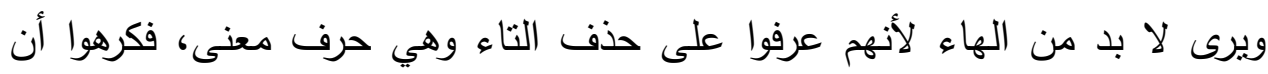

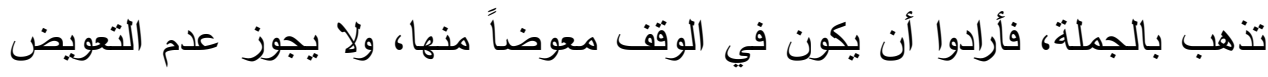

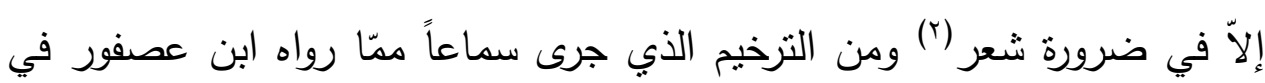
(ॅ): حذف التاء. قول جرير

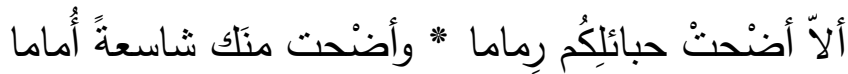

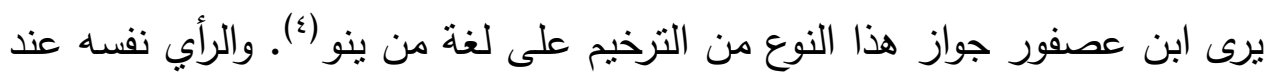
ابن الأنباري -من قبله- بجواز الثرخيم في غير النداء لضرورة الثعر (॰).

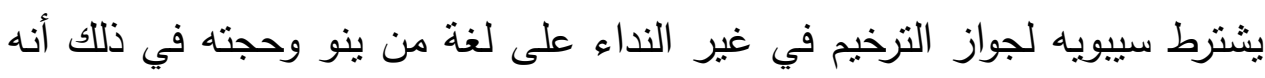

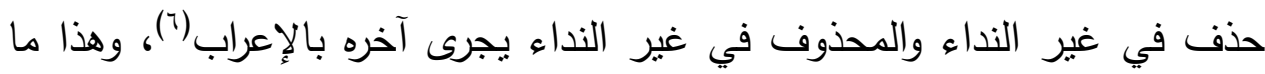
يراه البصريون بأنه ترك الميم على لفظها مفتوحة على لغة من ينو "ينظظر"، وهي لني

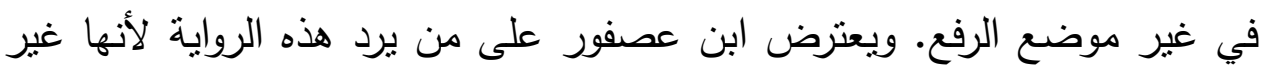

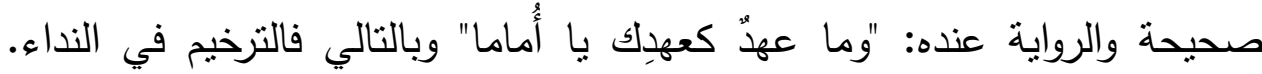

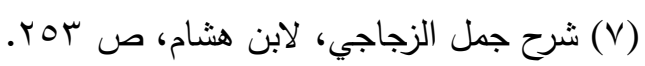

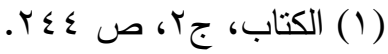

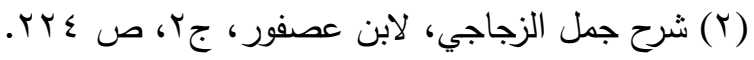

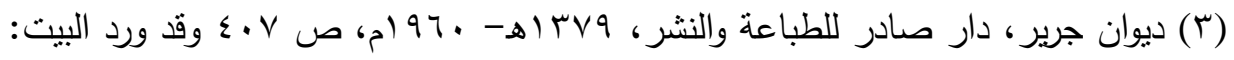

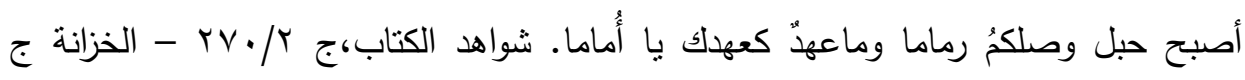

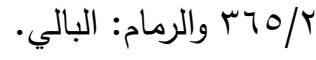

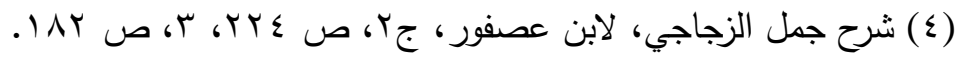

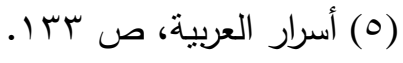

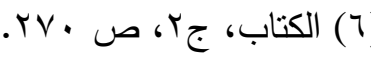


ويقول ابن عصفور أن هذه الرواية لا تصمد أمام رواية سيبويه وغيره من البصريين(Y). ويوافقه ابن هشام على ضعف الرّواية وأن هذا في غير النداء وهو سماعي، لأن تقديره: " وأضحت أمامة منك شاسعة". و مما رخم في غير النداء(') ومن الترخيم قول الثاعر:

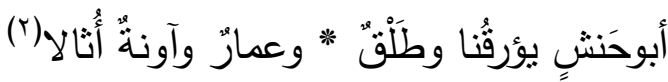

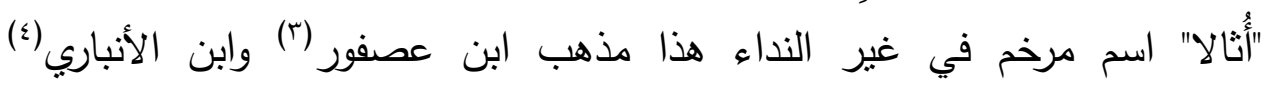
وسيبويه.(0) وعند غيرهم أنُ "أُثالا" معطوف على الضمير في يؤرقنا المنصوب كأنه قال: يؤرقنا ويؤرق " أثالا"(T)، وأنه ليس في كلام العرب أثالة، وإنما هي أثنال ونصب آنب على تقدير يذكرني آونة أُثالاً"(V). ويزعم السيرافي أن "أثنالا"، ليس على ماقاله المبرد، ولا ماقاله سيبويه لأن قول المبرد

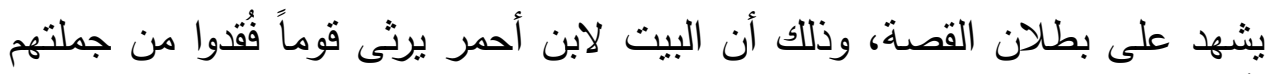

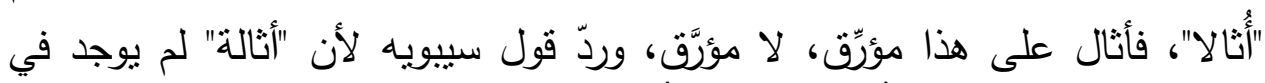

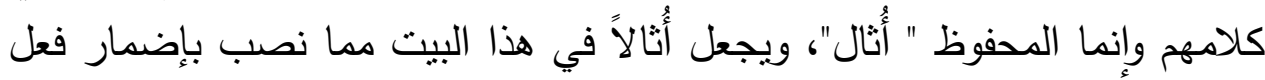

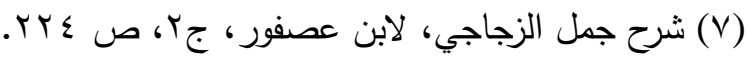

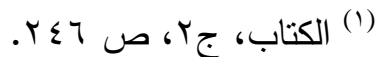

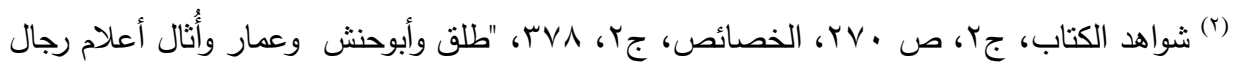
رفقاء الثاعر .

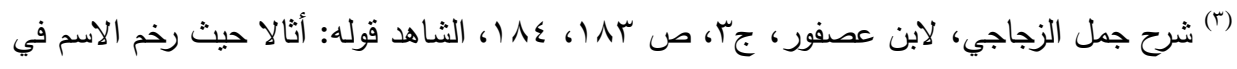
غير النداء.

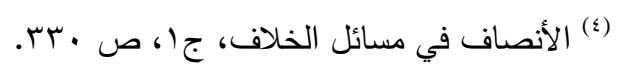

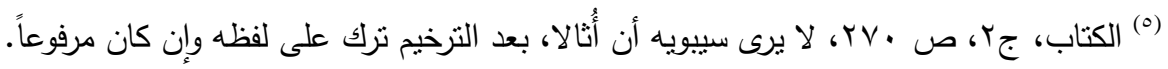

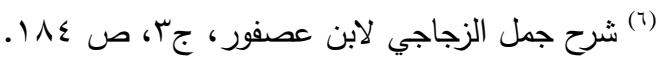

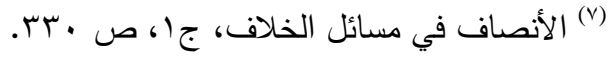

$$
\begin{aligned}
& \text { TVV }
\end{aligned}
$$


بدلالة ماتقدم عليه، لأنه إذا أرقّه "عباد وطلق" وأبوحنش فقد يذكر "أثنالا" لأنه من

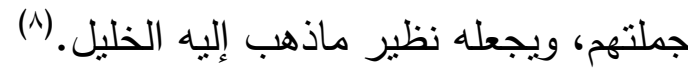

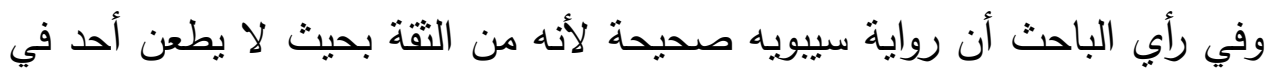

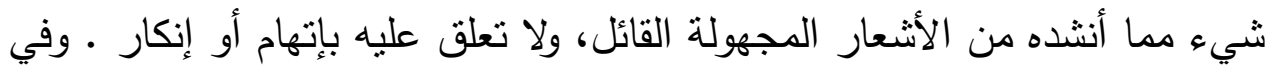

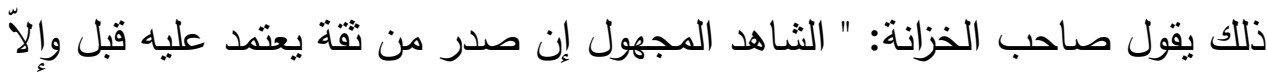

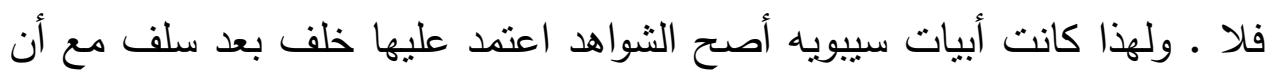

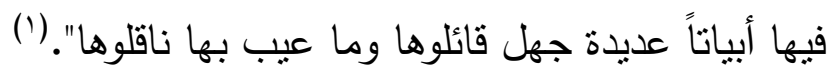

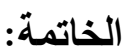

وبعد، فهذا بحثُ مختصرٌ عن مذهب السماع في أصول النحو بين عالمين جليلين،

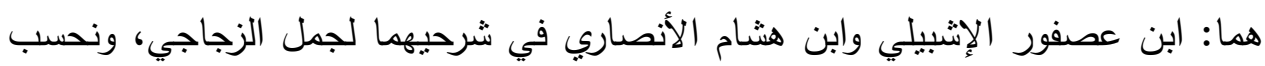

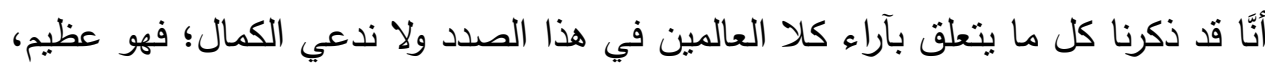

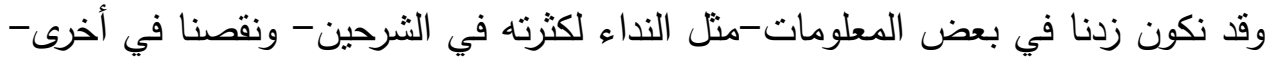

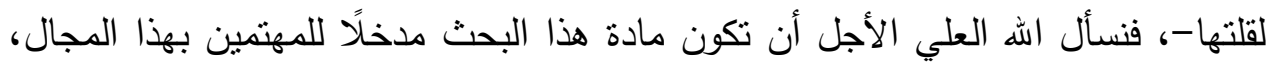

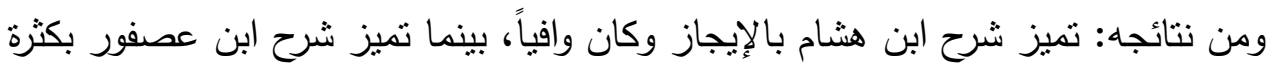
الموضوعات التي تناولها، وقد حرص ابن هشام على السير في شرحه للسماع وفقاً لترتيب

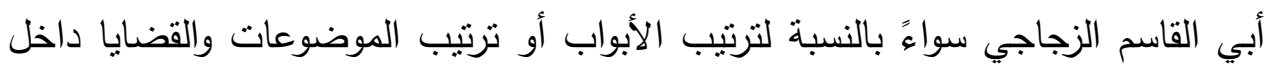

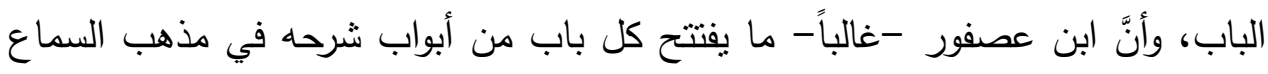

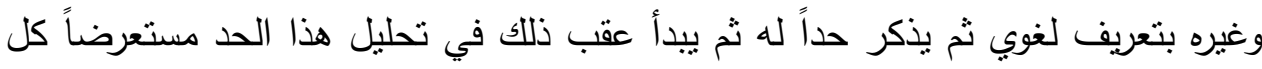

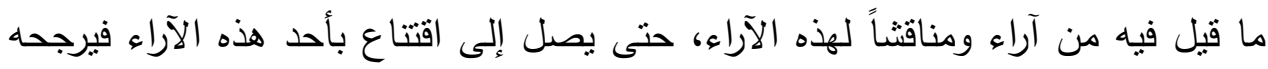

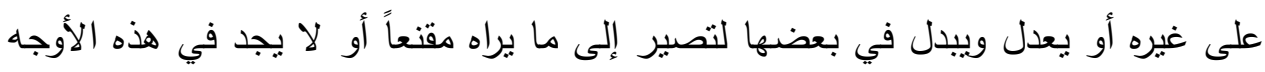

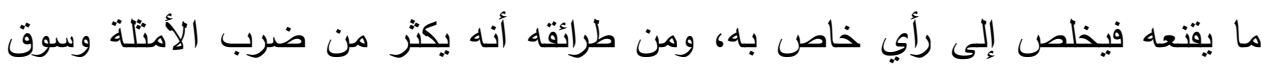
الثواهد للمسألة الواحدة وهي طريقة من شأنها تثبيت القاعدة في ذهن السامع وتقريبها إلى بهى

$$
\begin{aligned}
& \text { (^) شرح جمل الزجاجي لابن عصفور ، جr، ص ع^ا. }
\end{aligned}
$$

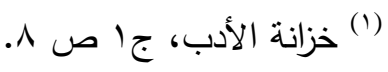


فهمه ولكن ذللك مشروط بعدم الإكثار من التمثيل كثرة تنسي جوهر القاعدة، و كانت طريقته في عرض آراء النحويين وأفكارهم وتعليلاتهم واختلافاتهم واعتراضاتهم وما قدموه من بين يدي هذا من الحجج والبراهين تتمثل غالباً في أنه يبدأ بذكر رأي البصريين ممثناً في سييويه ثم يستعرض بعد ذلك آراء النحوبين الآخرين من متقدمين ومنآخرين فيناقش ويحاور ويحلل ثم يرجح ما يرى أنه الصواب، وأحياناً لا يرجح بل يكتقي بالسرد فقط، لأنه ربما يرى أن هذه الآراء متكافئة، وقد حوى هذا الكتاب- جمل الزجاجي- كثيراً من الآراء النحوية والنصوص مما يجعله خزانة لما ظن أنه اندثر في تراث العربية، فنوصي بالرجوع إليه ودراسته دراسة مستفيضة للخروج بقواعد تعين الدارسين، والمختصين. 


\section{المصادر والمراجع}

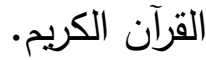

1- أسرار العربية، ابن الأبناي " أبو البركات كمال الدين عبدالرحمن بن محمد"،

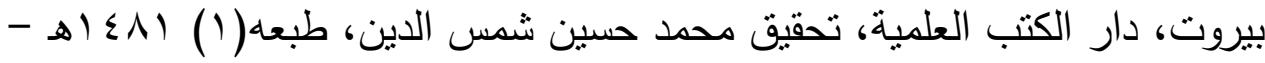

$$
\text { . } 199 \mathrm{~V}
$$

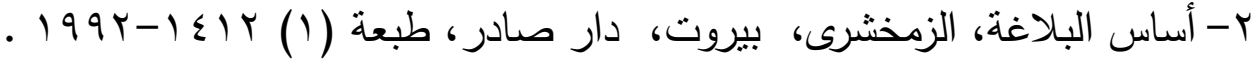

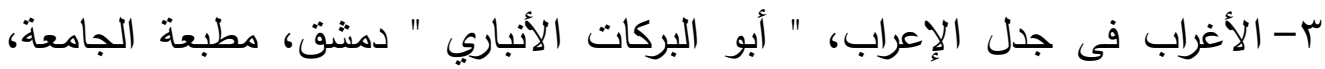

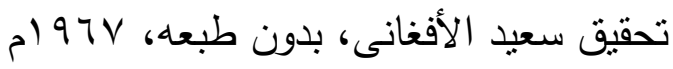

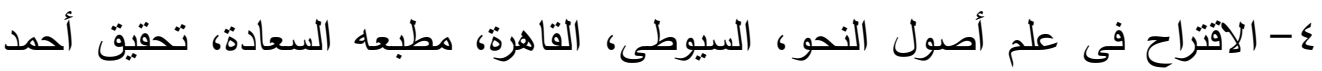

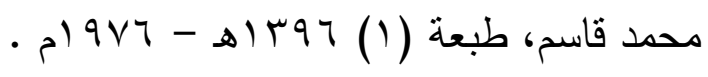

ه- الإنصاف فى مسائل الخلاف بين النحويين البصريين والكوفيين، ابن الأنباري،

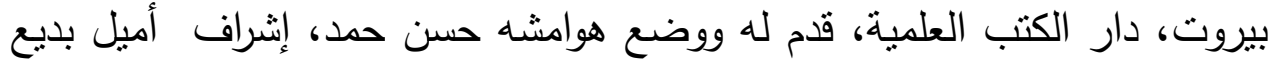

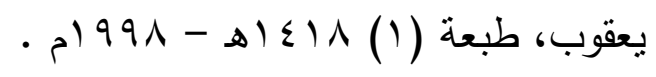

צ- التبصرة والتذكرة ، الصيمرى، دمثق، در الفكر، تحقيق فتحى احمد مصطفى، طبعة

$$
\text { - } 9194 \text { ، (1) }
$$

V- التنيان في إعراب القرآن، العكبرى " أبو القاسم عبداله بن الحسين"، مصر، تحقيق

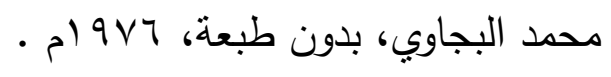

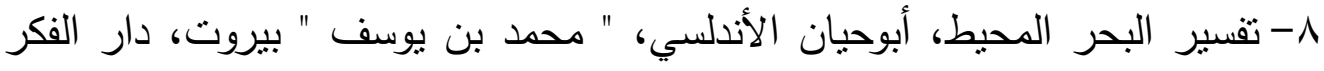

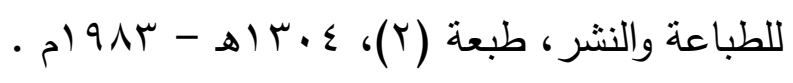

9- خرانة الأدب، البغدادى " عبد القاهر بن عمر " مصر ، الهيئة العامة للكتب، تحقيق

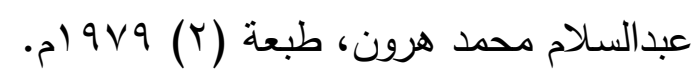

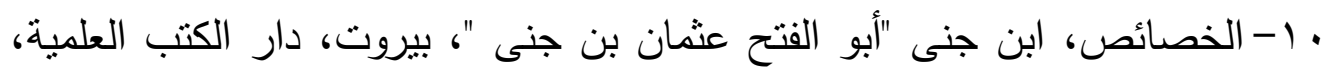

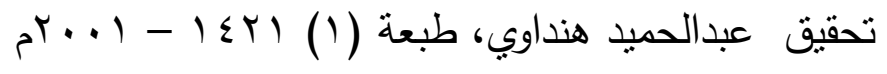

$$
\text { rA. }
$$


ا ا-ديوان الحطيئة " جرول بن أوس بن جؤبة بن مخزوم" القاهرة، مطبعة المدنى،

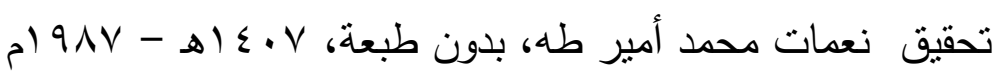
r ا-ديوان جرير، "بن عطية الخطفى"، دار صادر للطباعة والنشر، تحقيق كرم

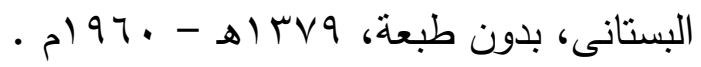

ب ا - ديوان طرفة بن العبد " سفيان بن مالك "، بدون طبعة، ، . 9 (م.

ع ا-ديوان لبيد بن ربيعة العامرى، بيروت، دار صادر بدون طبعة، جمشاهـ -

- 1974

1 -شرح ابن عقيل على ألفية ابن مالك، بيروت، دار المعرفة، علق عليه أحمد طعمة

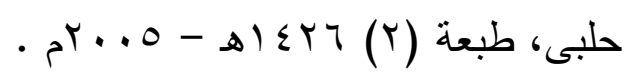

7 ا شرح الأشمونى على ألفية بن مالك، بيروت، دار الكتب العلمية، ثقديم حسن حمد،

$$
\text { بدون طبعة، } 9919 \text { - 19 19 }
$$

IV V شرح الكافية الثافية، ابن مالك، "أبو عبداله محمد جمال الدين"، دار المأمون

$$
\text { للتراث، تحقيق عبدالمنعم هربدى، بدون تاريخ طبعة . }
$$

1 ا-شرح المفصل، ابن يعيش " موفق الدين يعيش بن على بن يعيش النحوى"،

$$
\text { بيروت، عالم الكتب، بدون تاريخ طبعة . }
$$

9 ا-شرح جمل الزجاجى، ابن عصفور " أبو الحسن على بن مؤمن" بيروت، دار الكتب العلمية، قدم له ووضع هوامشه وفهارسه فوار الثعار، إثراف إميل بديع

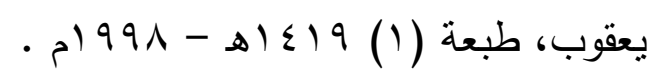

• ץ-شرح جمل الزجاجى، ابن هثام ، بيروت، عالم الكتب، دراسة وتحقيق على محسن

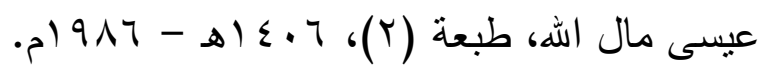

ا ץ-شرح ديوان حسان بن ثابت، بيروت، دار الكتاب العربى، ضبطه عبدالرحمن

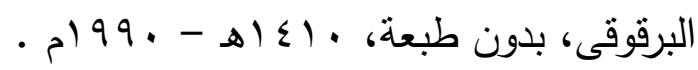


r r- القاموس المحيط، الفيروز آبادي " مجد الدين بن يعقوب " مصر ، شركة فن

$$
\text { الطباعة، طبعة (0) بدون تاريخ مون }
$$

سץ-قطر الندي وبل الصدى، ابن هشام الأنصارى، بيروت، دار الكتب العلمية، قدم له

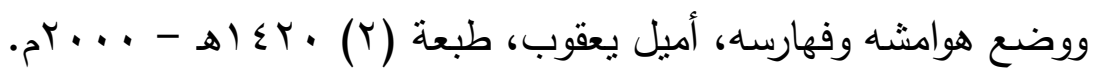

ع Y- الكتاب، سيبويه، " أبو البشر عمرو بن عثمان بن قنبر "، بيروت، دار الجيل، تحقيق وشرح عبدالسلام محمد هرون، طبعة ( ( ) بدون تاريخ.

هץ- كتاب التعريفات، الجرجانى "علي بن محمد بن علي الحسين"، بيروت، دار الكتب العلمية، وضع فهارسه محمد باسل عيون السود، بدون تاريخ طبعة . جr- لسان العرب ابن منظور " أبو الفضل جمال الدين محمد بن مكرم " دار المعارف، تحقيق عبداله الكبير، بدون تاربخ طبعة.

V V المحكم والمحيط الأعظم في اللغة، ابن سيدة، " على بن إسماعيل ابن سيدة، مكتبة ومطبعة مصطفى ألبابى الحلبى وأولاده، تحقيق مصطفى السقا، وحسن

$$
\text { نصار ، بدون ناريخ. }
$$

^ץ- المحرر في النحو، الهرمي، مصر، تحقيق منصور على محمد عبدالسميع،، دار

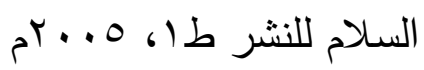

qץ- المساعد علي تشهيل الفوائد، ابن مالك، دمشق، دار الفكر، تحقيق محمد كامل

$$
\text { بركات، طبعة(1)، }
$$

• r- المعجم الوسيط، مجمع اللغة العربية، القاهرة، دار عمران، طس، بلون تاريخ. اس-المفصل فى صنعة الإعراب، الزمخشرى، بيروت، دار الكتب،بدون طبعة، - 1999

ץ- المقتضب، المبرد " أبو العباس محمد بن بزيد "، القاهرة، تحقيق محمد عبد

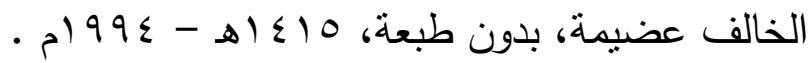


بس-نتائج الفكر في النحو ، أبو القاسـم السـهيلى " عبدالرحمن بـن عبداله "، جامعـة

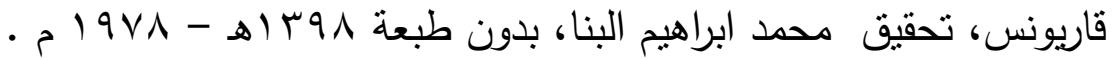

ع - همع الهوامع في شرح جمع الجوامع، السيوطى، بيروت، دار الكتب العلمية،

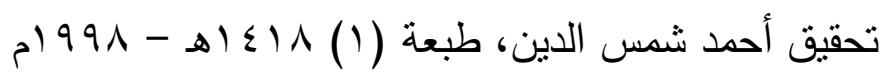

